OECDpublishing

THE CHANGING

CHARACTERISTICS

OF STEEL FIRMS

INSIGHTS FROM THE NEW

OECD STEEL DATABASE

OECD SCIENCE, TECHNOLOGY AND INDUSTRY POLICY PAPERS

December 2020 No. 97 


\section{2 | THE CHANGING CHARACTERISTICS OF STEEL FIRMS}

This paper was approved and declassified by the Steel Committee on 25 September 2020 and prepared for publication by the OECD Secretariat.

Note to Delegations:

This document is also available on O.N.E under the reference code:

DSTI/SC(2020)13/FINAL

This document, as well as any data and any map included herein, are without prejudice to the status of or sovereignty over any territory, to the delimitation of international frontiers and boundaries and to the name of any territory, city or area.

The statistical data for Israel are supplied by and under the responsibility of the relevant Israeli authorities. The use of such data by the OECD is without prejudice to the status of the Golan Heights, East Jerusalem and Israeli settlements in the West Bank under the terms of international law.

COECD (2020)

The use of this work, whether digital or print, is governed by the Terms and Conditions to be found at http://www.oecd.org/termsandconditions. 


\author{
By Filipe Silva and Fabien Mercier
}

(OECD Directorate for Science, Technology and Innovation)

Information on the structural characteristics of steel firms over time provides important insights into the dynamics of the steel industry and how this industry has been restructuring and adapting in a rapidly changing environment. This paper builds on data from the new and unique OECD Steel database to shed light on the micro determinants of changes in the steel sector. The OECD Steel database provides invaluable insights into the characteristics of steel plants and steel firms, and how they have evolved in the last 20 years. Results from the analyses in this paper suggest that the steel sector could benefit from increased business dynamism, while data show that economies of scale and technology are important factors influencing adjustment in the sector. The paper concludes by offering several different avenues for future research that could build upon the OECD Steel database.

Keywords: Steel, Structural adjustment, Microdata, Industrial policy

JEL codes: C81, D20, L20, L61, L52 


\section{THE CHANGING CHARACTERISTICS OF STEEL FIRMS}

\section{Acknowledgements}

This report was prepared by Filipe Silva and Fabien Mercier, who are responsible within the OECD Secretariat for the design and development of the OECD Steel database. This newly developed database provides the backbone for analytical work carried out to support the discussions of the OECD Steel Committee.

The authors would like to acknowledge the contribution of Peter Avery to Section 2.1.1 of the document as well as Valentina Burrai, Tomohiro Hijikata and Gianpiero Mattera for their contributions to the OECD Steel database. The authors are also grateful to Sarah Box, Koen De Backer, Anthony de Carvalho, Dirk Pilat and Michele Rimini for comments on earlier versions of the report. Sanela Bajrovic, Angela Gosmann Joseph Loux and Amar Toor provided editorial support. 


\section{Table of contents}

$\begin{array}{ll}\text { Acknowledgements } & 4\end{array}$

$\begin{array}{ll}\text { Executive Summary } & 7\end{array}$

1. Introduction 8

2. Structural change in the steel sector 9

2.1. An overview of key developments since $2000 \quad 9$

2.2. The importance of structural adjustment 17

3. The OECD Steel database 19

4. The changing characteristics of steel plants and steel firms 21

4.1. Business dynamism $\quad 21$

4.2. Steelmaking capacity and financial performance $\quad 28$

4.3. Labour adjustments $\quad 31$

4.4. Performance of steelmaking technologies $\quad 32$

4.5. Business structure and ownership $\quad 35$

5. Concluding remarks and suggestions for further research 38

5.1. Summary 38

5.2. Future research 39

$\begin{array}{ll}\text { Endnotes } & 41\end{array}$

$\begin{array}{ll}\text { References } & 43\end{array}$

Annex A. Variables and indicators used in the analyses 46

$\begin{array}{ll}\text { Annex B. Additional tables and figures } & 48\end{array}$

Tables

Table 1. Persistent poor financial performance, 2000-2019 31

Table A B.1. Geographical coverage of the OECD Capacity and Steel databases as of 31 June $2020 \quad 48$

Table A B.2. Coverage of the top 30 steel producing economies 


\section{THE CHANGING CHARACTERISTICS OF STEEL FIRMS}

\section{Figures}

Figure 1. Prices and profitability since 2000

Figure 2. Margin between steel and raw material prices 12

Figure 3. Evolution of the share of steelmaking technologies in steel production capacity 13

Figure 4. Evolution of the share of BOF capacity in selected economies 14

Figure 5. The longevity of steelmaking equipment 15

Figure 6. Number of major capacity upgrades or equipment replacement over time, 2000-2019 16

$\begin{array}{lr}\text { Figure 7. Low carbon related patents as a percentage of total patents } & 17\end{array}$

Figure 8. Units of observation in the OECD Steel database 2000-2019 20

Figure 9. Evolution of the number of new and closed steelmaking equipment 21

Figure 10. Changes in capacity 2000-2019 22

Figure 11. Changes in capacity across economies $\quad 23$

$\begin{array}{lr}\text { Figure 12. The vintage and size of firms investing in new capacity } & 24\end{array}$

Figure 13. Distribution of indebtedness by plant age, 2000-2019 25

Figure 14. Firm growth 26

$\begin{array}{lr}\text { Figure 15. Financial performance and the probability of closure } & 27\end{array}$

$\begin{array}{lr}\text { Figure 16. International groups and the probability of closure } & 28\end{array}$

Figure 17. Evolution of profits and capacity, 2000-2019 29

Figure 18. The profitability of steelmaking capacity varies across years and geographies 30

Figure 19. Evolution of labour intensity, 2000-2019 31

Figure 20. Labour intensity by technology, 2000-2019

Figure 21. Profitability: BOF vs EAF, 2000-2019 33

Figure 22. Evolution of the average size of steelmaking plants by technology, 2000-2019 34

Figure 23. Predominant technology in new capacity investments and closures 35

Figure 24. Comparing the financial performance of international groups with producers, 2000-2019 36

Figure 25. Comparing the financial performance of single- and multi-plant firms, 2000-2019 36

Figure 26. Comparing the performance of State enterprises with private companies, 2000-2019 37

Figure A B.1. OECD Steel database and ORBIS coverage, 2000-2019 49

Figure A B.2. Financial performance by technology 51

Figure A B.3. Average annual firm growth across different dimensions, 2009-2019 52 
Information on the structural characteristics of steel firms over time provides important insights into the dynamics of the steel industry and how this industry has been restructuring and adapting in a rapidly changing environment. A better understanding of the functioning of the steel industry supports the design of better policies to promote structural adjustment and help resolve steel excess capacity.

This paper builds on data from the new and unique OECD Steel database to shed light on the micro determinants of changes in the steel sector. This internal OECD Steel database provides invaluable insights into the characteristics of steel plants and steel firms, and how they have evolved in the last 20 years.

Data show that the 2008-09 financial crisis was an important turning point in the steel industry that was followed by a long and pronounced global excess capacity crisis. The steel industry will likely face additional challenges in the near-term, including a negative demand shock arising from the recent health crisis, calls for additional efforts to address environmental challenges, socio-economic trends that lower the intensity of steel use, as well as sudden shifts in the availability and prices of raw material and energy inputs.

Meeting the upcoming challenges requires addressing the longstanding structural imbalances in the sector. Structural adjustment can take different forms and the steel sector has been adjusting through changes in labour intensity, changing business structure and upgrading of outdated technology. Nevertheless, results from the analyses in this paper indicate that the steel sector is characterised by low business dynamism and suggest that the market mechanism is not working efficiently. On the one hand, there is no apparent relationship between financial performance and exits, which could be explained by nonmarket barriers to exit. On the other hand, large incumbents seem to make the majority of new investments in steelmaking capacity, which likely reflects high set up costs and other barriers to entry.

Data also show that economies of scale and technology are important factors influencing adjustment in the sector. For example, data show that while multi-plant firms perform better than single-plant firms and international business groups may benefit from financial and other advantages, capacity reductions or closures seem less likely to take place in multiplant firms and in multinationals.

Evidence on how different characteristics relate to capacity and economic performance supports the development of targeted policies that can facilitate restructuring and ensure long-term sustainability of the sector. The analyses in this paper suggests that market entry and exit mechanisms should be allowed to work. Furthermore, restructuring through mergers and acquisitions and changes in the internal organisation of companies' production units should be facilitated, as long as competitive conditions are maintained and changes result in a leaner industry that is prepared for the challenges ahead. Upgrading technology towards more flexible, more efficient and cleaner production processes could also help prepare for future challenges.

This paper concludes by offering several different avenues for future research that could build upon the OECD Steel database. While some areas of research could be carried out by the OECD in the context of future work programmes of the Steel Committee, others are better suited for academic researchers who would be interested in contributing further evidence on the functioning of the steel sector. 


\section{Introduction}

Information on the structural characteristics of steel firms over time, such as changes in technology used, productivity, business organisation, ownership, among others, provides important insights into the dynamics of the steel industry and how this industry has been restructuring and adapting in a rapidly changing environment. Evidence on how different steel plant and firm characteristics relate to steel production capacity and financial performance also supports the development of targeted policies that can facilitate the restructuring of the industry and ensure its long-term sustainability.

This paper builds on data from the new and unique OECD Steel database to shed light on these issues. The OECD Steel database provides invaluable insights into the characteristics of steel plants and steel firms and on how they have evolved in the last 20 years. Results from the analyses in this paper suggest that the steel sector could benefit from increased business dynamism, while data show that economies of scale and technology are important characteristics factors influencing adjustment in the steel sector. The development of the OECD Steel database has been steered by the Steel Committee and will continue to be maintained and updated so that further plant- and firm-level analyses on different aspects affecting the performance of the steel industry can be carried out in the future.

This document is organised as follows. Section 2. sets the stage for the analysis by reviewing important changes in the steel sector since 2000 and highlighting the importance of structural adjustment. Section3. describes the OECD Steel database, while Section 4. presents and discusses some evidence on the changing characteristics of steel plants and firms. Section 5. brings together the main results of the analyses and offers suggestions for further research. 


\section{Structural change in the steel sector}

\subsection{An overview of key developments since 2000}

Since the early 2000s, the steel sector has undergone a number of significant transformations, including recurring excess capacity crises, gradual changes in steelmaking technology and the automation and digitalisation of production processes, as well as shifts in the supply of the different raw materials together with disruptions in supply chains and the deterioration of the quality of some raw materials. And it does not stop here as new challenges are emerging for steel companies. The challenges ahead include, for example, navigating the negative demand shock arising from the recent health crisis, intensifying efforts to address environmental challenges and further integrating in a circular economy, adjusting to socio-economic trends that affect the intensity of steel use and long-term steel demand, as well as adapting to sudden shifts in the availability and prices of raw material and energy inputs. These challenges add to the longstanding structural imbalances in the sector and require structural changes that help make the industry leaner and ensure its longterm viability.

\subsubsection{An industry enduring several crises}

The steel industry has established a pattern of moving from boom to bust for many decades, largely driven by mismatches between production capacity and demand. Those mismatches are due to a number of industry characteristics including government interventions and structural factors such as set-up costs, the lead-time required between the planning of new capacity and its effective deployment, imperfect foresight and overoptimistic demand expectations, as well as important economic and social closure costs that add to the challenges of adapting to lower demand.

Concern about overinvestment occurred as early as 1949, when the secretariat of the United Nations Economic Commission for Europe (UNECE) carried out a study of the long-term demand for steel at a global level (Berthelot and Rayment, $2007_{[1]}$ ). The study, which was to have an important influence on the Schuman Plan, underscored the risks of creating too much capacity. The first global steel crisis arose in the 1970s with the recession following from the first global oil shock. Steel demand collapsed even as new capacity was coming on stream in line with previous expectations of a robust and long-term growth of the sector. Intervening crises occurred in the decades that followed, to lesser extents, until the global economic crisis of 2008, which precipitated a collapse in industry fortunes worldwide.

As in the 1970s, global excess capacity was the main driver of the industry's recent woes, giving rise to formidable trade and adjustment challenges. The general increase in the world's steel demand during the early 2000 s was accompanied by a very rapid increase in global steel production capacity. At the onset of the 2008-09 financial crisis, several companies were making important investments to build new capacity in order to be able to meet the rapidly increasing demand. The financial crisis gave a first blow to the sector, which was kept buoyant by stimulus packages introduced around the world, notably in the People's Republic of China (hereafter 'China'). However, new steelmaking facilities were still being deployed or were in the planning stages in many jurisdictions (OECD, 2014 ${ }_{[2]}$ ).

With the deceleration of Chinese economic growth in the 2010s, modest increases in global steel demand were no longer absorbing all the supply that had come on stream and by 2015 , global prices and profitability were at historical lows (Figure 1). These imbalances resulted in the most recent and prolonged excess capacity crisis, from which the global steel industry 
has not yet recovered. Looking at the future, important changes in the economy and the society may impact long-term steel demand: changing demographics and increased urbanisation, automation and digitalisation, the move towards a circular economy focused on re-cycling, re-using and re-manufacturing, as well as lower intensities of steel use and the decoupling of GDP growth and steel consumption.

Figure 1. Prices and profitability since 2000

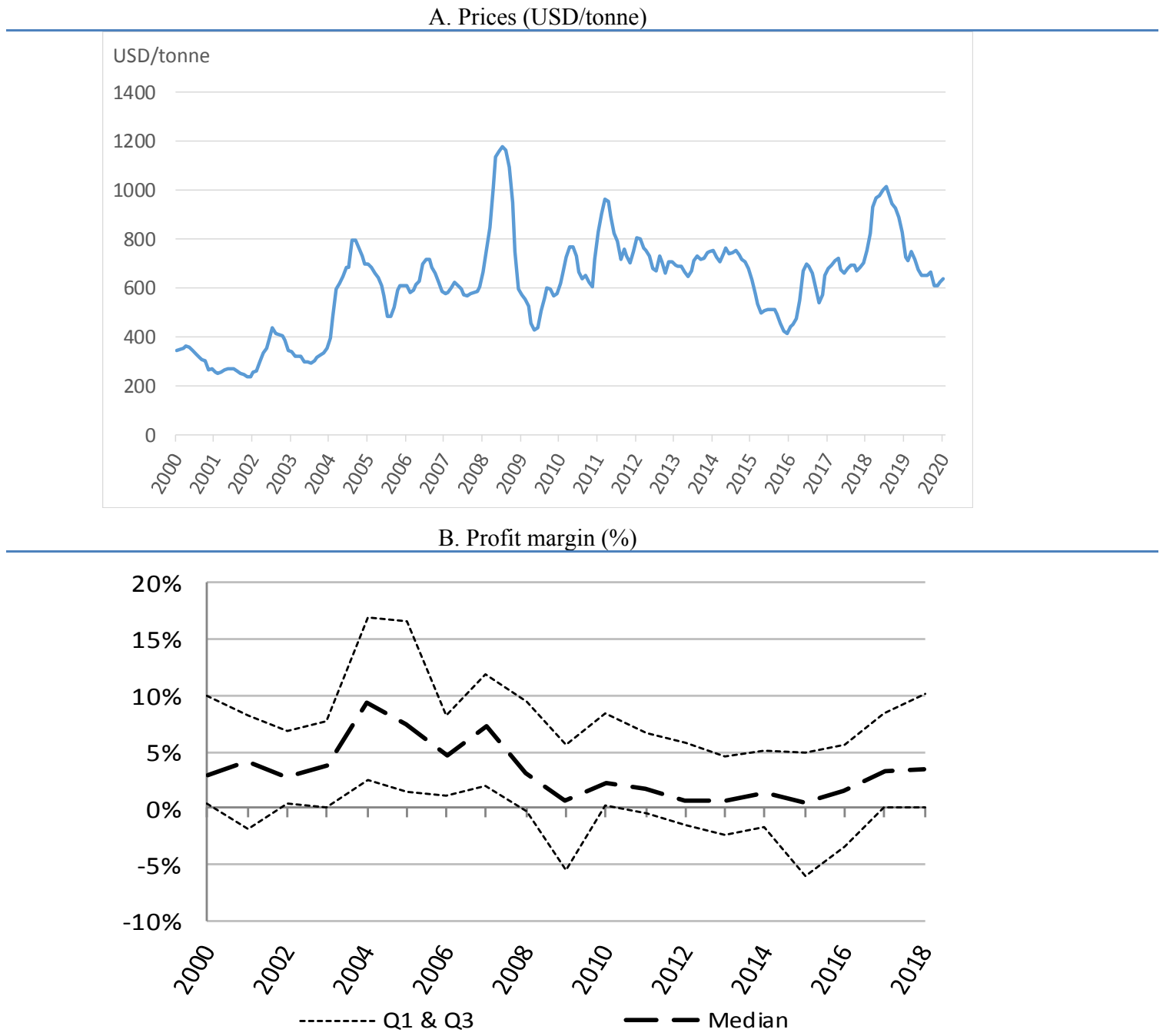

Note: Panel A shows the evolution of the monthly US flat price in USD per metric tonne, between 01/01/2000 and 01/01/2020, as captured by Platt's index "Flat Products / Platts TSI HRC / US domestic EXW Midwest $\$ / t$ ", chosen due to its longer time-span compared to other Platts' series. Panel B shows the evolution of the median, first quartile and second quartile of the annual profit margin distribution across plants.

Source: Platts for the price series and OECD Steel database for profitability.

Faced with a new global economic crisis in 2020, sparked by the Covid-19 pandemic and growing excess capacity, the steel industry needs to intensify restructuring efforts, probably more in some geographies. The way in which adjustments are made - i.e. which plants and which firms will ultimately close and which ones will strive - will underpin the sector's long term performance, including its financial, economic and environmental sustainability. These adjustments are also likely to have long-term consequences on the 
economies of steel producing jurisdictions and affect steel workers in particular minimising the socioeconomic impact of underlying restructuring processes will be important.

\subsubsection{Raw materials and the balance of steelmaking technologies}

The steel sector is also affected by fluctuations in steelmaking raw material markets and supply shocks. Steelmaking raw material prices are characterised by considerable volatility (Daniel, 2013 [3]) and reflect a number of distortions caused by policy interventions, notably affecting international trade of these materials (OECD, 2020 $0_{[4]}$ ). The deterioration of iron ore and coking coal quality and the exposure of raw materials supply chains to disruptions are important concerns for steel producers (worldsteel, 2020 $0_{[5]}$ ). For example, the rapid increase in variable costs after 2004, and notably after the 2008-2009 financial crisis, was mainly driven by the rise of raw material prices (Silva and de Carvalho, 2016 6 ), amidst a tightening of commodity markets after the 2008-2009 financial crisis.

While steel prices follow a relatively similar trend, steel producers however appear to struggle to maintain price margins and transfer costs to clients, at least in the aftermath of significant raw material price swings. Price margins in the steel industry seem to get squeezed during raw material price increases. Figure 2 illustrates three instances when this occurred: in 2003-04, when mining capacity was becoming scarce to meet the rapidly increase demand from steel production; during the commodity boom in 2011, after the 2008-09 financial crisis and when price margins reached their lowest levels since 2003; and more recently in 2016 when raw material prices started to recover from overinvestment and amidst modest improvements in expectations about steel markets. 


\section{Figure 2. Margin between steel and raw material prices}

Monthly data: November 2003- May 2020

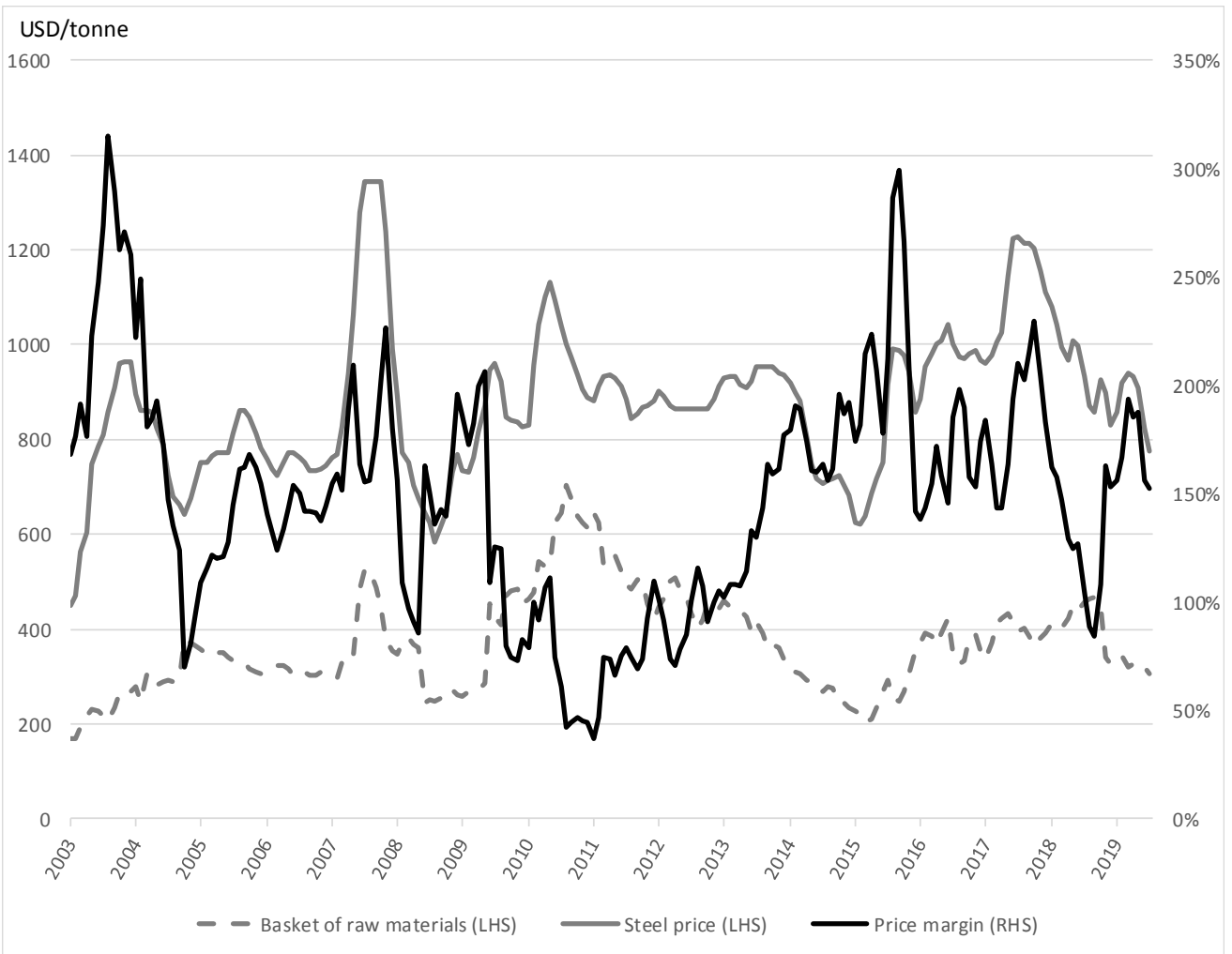

Note: The raw materials basket for steel production includes $70 \%$ of the usual quantities of iron ore (1.6 tonne) and coking coal ( 0.77 tonne) needed to produce steel in the integrated process and $30 \%$ of the quantity of ferrous scrap (1.07 tonne) needed to produce steel in the electric arc furnace process (Daniel, 2013 [3]). Prices used are as follows: Iron ore pellet 65\% Fe Brazil FOB; "Premium Coking Coal Australia" from Datastream from 2013 onwards, complemented by "Hard coking coal spot, FOB Australia" from Platts for the dates prior to 2013 ; Scrap, \#1 HMS, FOB Rotterdam. The basket is compared against steel prices indicated in Platt's series "Flat Products / Platts TSI HDG, incl. G90 / US domestic EXW Midwest", in USD per metric tonne. The price margin is defined as the per cent difference between the steel flat price and the raw materials basket price. Source: OECD based on data from Thomson Reuters, Platts Steel Business Briefing (SBB), and Datastream.

Changes in the relative prices of raw materials are intrinsically related to developments in steelmaking technology. On the one hand, the choice of technology is influenced by the local availability (and price) of key steelmaking ingredients. For example, high quality iron ore at a low price may justify investments in basic oxygen furnace (BOF) technology, while a developed local recycling industry that can efficiently supply ferrous scrap may drive investments in electric arc furnace (EAF) technology. On the other hand, capacity investments in a technology route shape future demand for the underlying key steelmaking ingredients.

Figure 3 shows the evolution of the share of steelmaking technologies in global crude steel production capacity. Even though EAF technology might be more attractive because of higher flexibility to adjust production (Silva and de Carvalho, 2016 $6_{[6]}$ ), increased ferrous scrap availability and environmental considerations (OECD, 2015 $\left[5_{[7]}\right)$, BOF technology continues to be the main steelmaking route, accounting for more than two thirds of global steelmaking capacity in 2019 (67.2\%). Together with EAF technology, which accounts for slightly less than a third of global capacity $(31.4 \%)$, these are the two predominant steel production routes. 
With regards to other technologies, open-hearth furnaces (OHF) have been gradually replaced (accounted for over $2.5 \%$ of global capacity in 2000, but less than $0.5 \%$ in 2019) and induction furnaces (IF) still account for less than $0.7 \%$, despite some recent interest possibly related to low set up costs and higher flexibility (Hijikata, 2020 ${ }_{[8]}$ ).

Figure 3. Evolution of the share of steelmaking technologies in steel production capacity

Share of world total capacity, 2000-2019

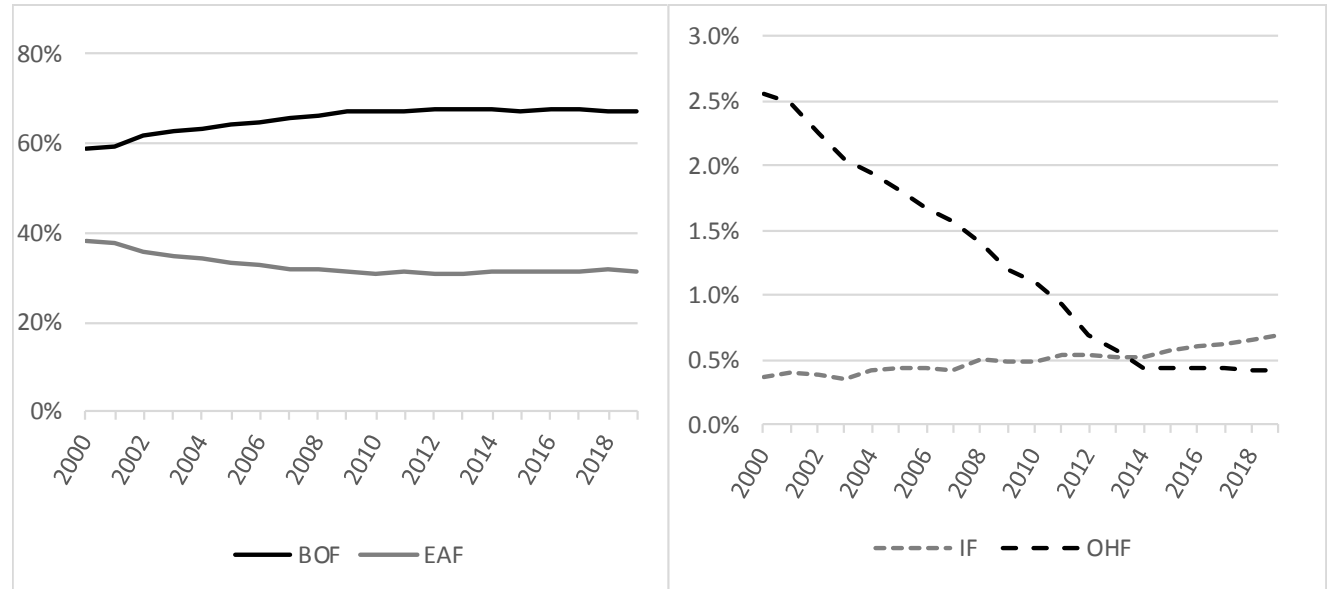

Source: OECD Steel database.

The balance of steel technologies varies significantly across geographies, reflecting natural endowments, among others. For example, while Iran relies almost exclusively on EAF technology, BOF technology accounts for $87 \%$ of total steelmaking capacity in China. ${ }^{1}$ Figure 4 shows the share of BOF technology since 2000 for the top five economies in terms of net capacity increases since the 2008-09 financial crisis. With the exception of Iran, where most of the new investments were in EAFs, BOF technology continues to prevail and accounts for at least $50 \%$ of total capacity in each of the remaining top- 5 economies. 


\section{Figure 4. Evolution of the share of BOF capacity in selected economies}

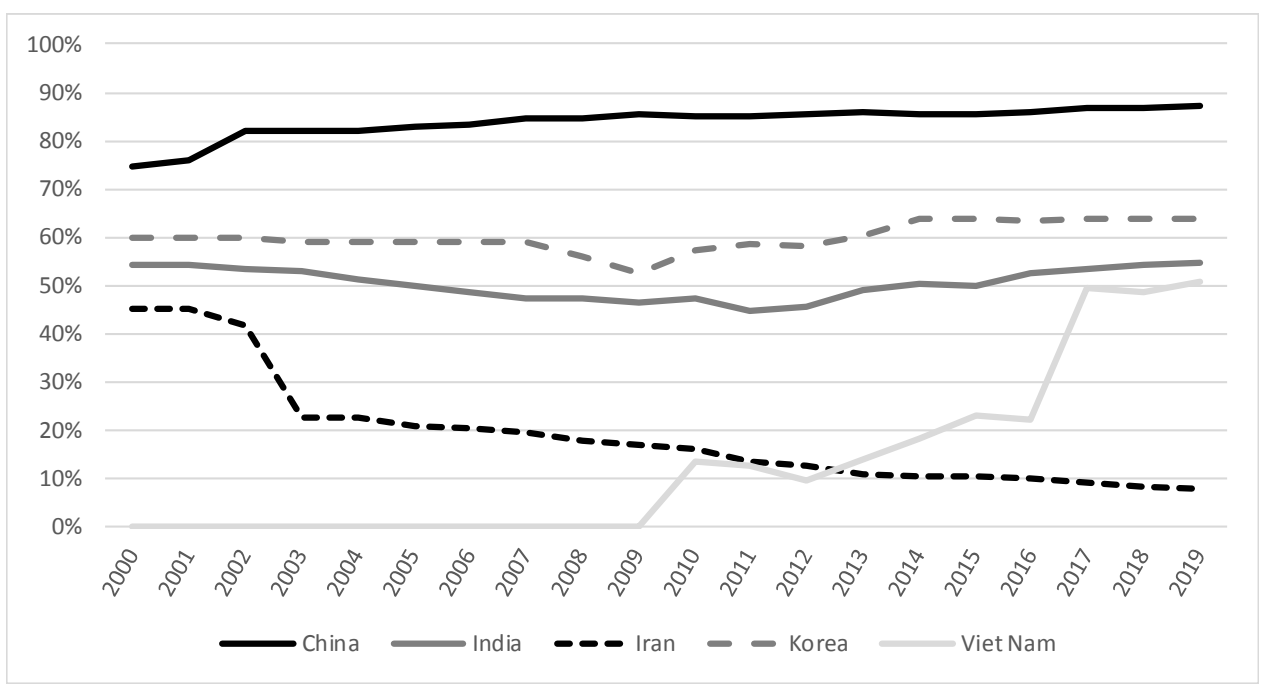

Note: The economies listed in the figure were selected based on the largest net steelmaking capacity increases (in mmt) during the period 2009-2019. During this period, crude steelmaking capacity increased by $268 \mathrm{mmt}$ in China, $52 \mathrm{mmt}$ in India, $25 \mathrm{mmt}$ in Iran, $22 \mathrm{mmt}$ in Korea and $19 \mathrm{mmt}$ in Viet Nam.

Source: OECD Steel database.

In the absence of a shift towards other technologies in the medium-term, iron ore, coking coal and other key steelmaking ingredients for the BOF technology will continue to be in high demand. Nevertheless, looking further ahead, carbon emission regulations, the increasing focus on promoting a circular economy, and growing steel scrap reservoirs may create incentives for a gradual decline in the use of BOF technology. In contrast, investments in EAF technologies could be expected to increase, given the efficiency, feedstock flexibility and environmental advantages. Moreover, while the costs of deploying new breakthrough steelmaking technologies can be considerable, this could take place sooner than expected in response to calls for cleaner steelmaking technologies (see Section 2.1.4).

\subsubsection{Innovation and changes in steelmaking technology}

Innovation plays a significant role in the steel industry, helping to boost productivity through improvements in production processes and the development of new products with enhanced properties. New casting techniques, more advanced steel rolling processes, and better monitoring and control systems, for example, have reduced the number of discrete steps in the production process. Product innovation has resulted in the development of products with better corrosion resistance, higher strength-to-weight ratios and greater heat resistance. In some cases, the introduction of new technologies has intensified competition among producers, with the reallocation of production to newer facilities resulting in higher aggregate industry productivity (Collard-Wexler and De Loecker, 2015

High industry entry barriers, the complex structure of the industry, high sunk costs and high barriers to exit (Rimini et al., 2020[10]) result in a considerable time lapse between an innovation, the deployment of a new technology and its dissemination. The shift from OHF to BOF was particularly challenging for established firms at the time, because incumbents had already made substantial investments in their OHF plants. In contrast, the adoption of the technology in brand new facilities was straightforward. New technologies may however have lower capital requirements, thus reducing the opportunity costs of shifting from an 
older technology. Moreover, the maintenance costs for the older technology can be significant. For example, the capital requirements (measured as the cost per production capacity of one metric tonne) for constructing an EAF "minimill" have been found to be almost half of those of an integrated producer. In addition, the cost of a blast furnace reline can sometimes be close to the cost of setting up a new "minimill" (D'Costa, 1999 [11]). Incremental innovations are also very important. For example, improvements to the electric arc furnace (EAF) technology went hand-in-hand with substantial gains in terms of energy efficiency and productivity (Silva and De Carvalho, 2016 $\left.{ }_{[12]}\right)$.

Steelmaking equipment typically remains in operation for several decades (Figure 5). The longest lasting piece of equipment in the sector so far was an OHF that closed in 2011, after 129 years in operation. While it is reasonable to assume that equipment can last decades, it does so in many cases because of refitting, modernisation and other upgrades that prolong the life of the equipment and help ensure it remains productive. Upgrading or replacing outdated equipment is another important form of adjustment that can help firms keep competitive.

\section{Figure 5. The longevity of steelmaking equipment}

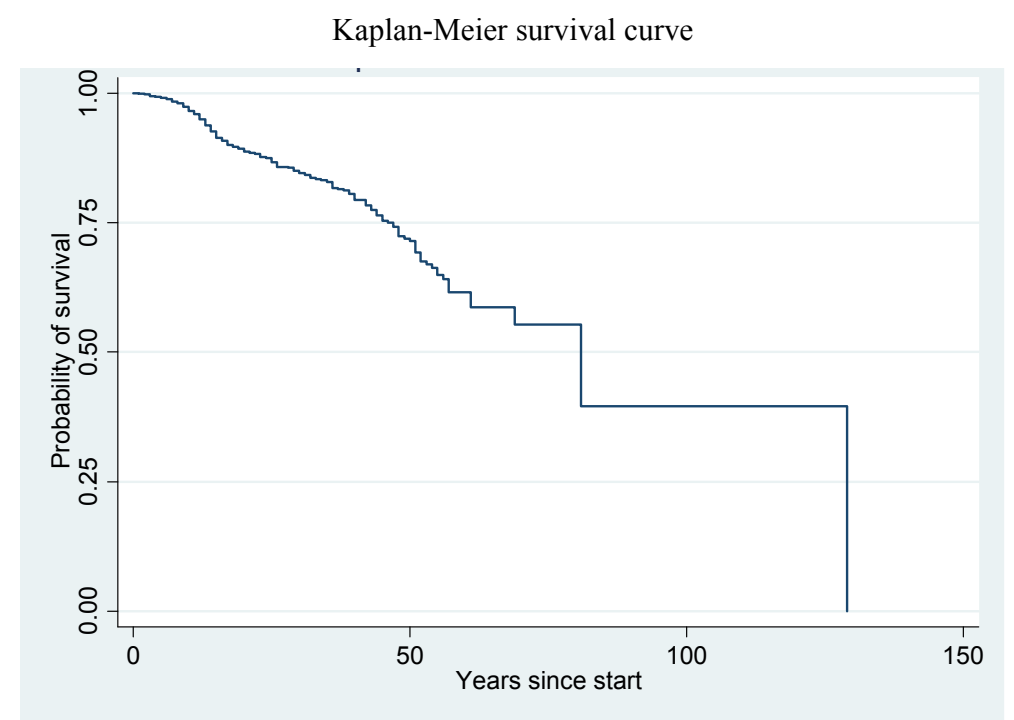

Note: The Kaplan-Meier survival curve estimates the probability of survival over time by computing the number of units remaining in operation at each point in time in the sample.

Source: OECD Steel database.

Information on major upgrades and replacement of equipment in the OECD Steel database is still work in progress. Preliminary estimates show that major upgrades of steelmaking capacity seem to have intensified since the late 2000 s, with a temporary slowdown during the years 2015-16 (Figure 6), when the financial situation of steel companies was particularly dire (OECD, 2017 $7_{[13]}$; Silva and de Carvalho, 2016[6]). Plants investing in capacity upgrades appear to be younger and larger - the median age (size) of plants that invest in an upgrade is six years $(2.2 \mathrm{mmt})$, compared to 16 years $(0.8 \mathrm{mmt})$ for those that do not upgrade equipment. 
Figure 6. Number of major capacity upgrades or equipment replacement over time, 2000-2019

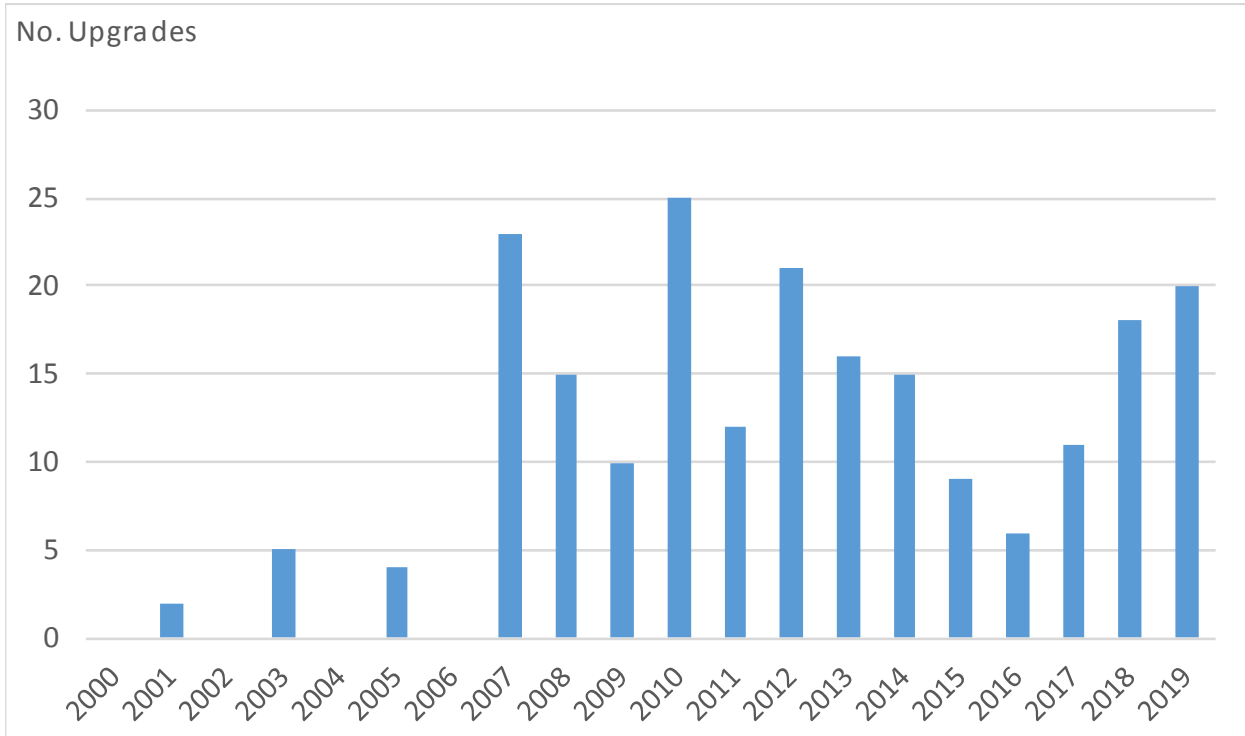

Note: The figure counts the number of events each year that resulted in either a major upgrade of steelmaking equipment or its replacement by a new equipment. The OECD Steel database focuses on nameplate capacity, but it is nevertheless important to register any "major" capacity increase resulting from modernisation, relining or other improvements made to the steelmaking equipment. Minor upgrades are not registered in the database. The assessment of "major" is left to the discretion of the Secretariat's staff investigating the specific plant and event, but it should follow a rule of thumb to register any upgrade that results in either more than $0.20 \mathrm{mmt}$ of additional capacity or more than $20 \%$ of the equipment's capacity. In this figure, replacements of equipment with the same technology are not distinguished from those resulting in different technologies.

Source: OECD Steel database.

\subsubsection{The move towards cleaner technologies}

Faced with increasing environmental concerns, the steel industry has been moving towards cleaner and more efficient ways of producing steel. While energy efficiency has improved substantially over the last two decades, there is considerable room for improvement, notably in terms of the dissemination and adoption of best-available technologies and energy efficiency management practices.

Likewise, a number of new breakthrough steelmaking technologies are currently in the development or pilot phases. Examples include the use of hydrogen to process iron ore and yield water as a by-product (instead of carbon dioxide), or systems to capture (carbon dioxide) emissions for storage and potentially usage. The commercialisation and deployment of these technologies at large scale could help the industry take significant steps towards cleaner steel production.

Previous analyses of the environmental performance of the steel sector showed that the direction of invention in steel-related technologies started turning towards climate change mitigation during the first decade of this century (OECD, 2015 $\left.{ }_{[14]}\right)$. While there was a strong increase in the share of carbon mitigation related patenting activity in steel technologies since 2000, this trend stopped after the financial crisis of 2008-09 (Figure 7). Further analysis could combine patent data with the OECD Steel database to provide better insights into patenting steel companies and monitor the evolution of steel technologies. 
Figure 7. Low carbon related patents as a percentage of total patents

Steel versus all technological fields, 1970-2012

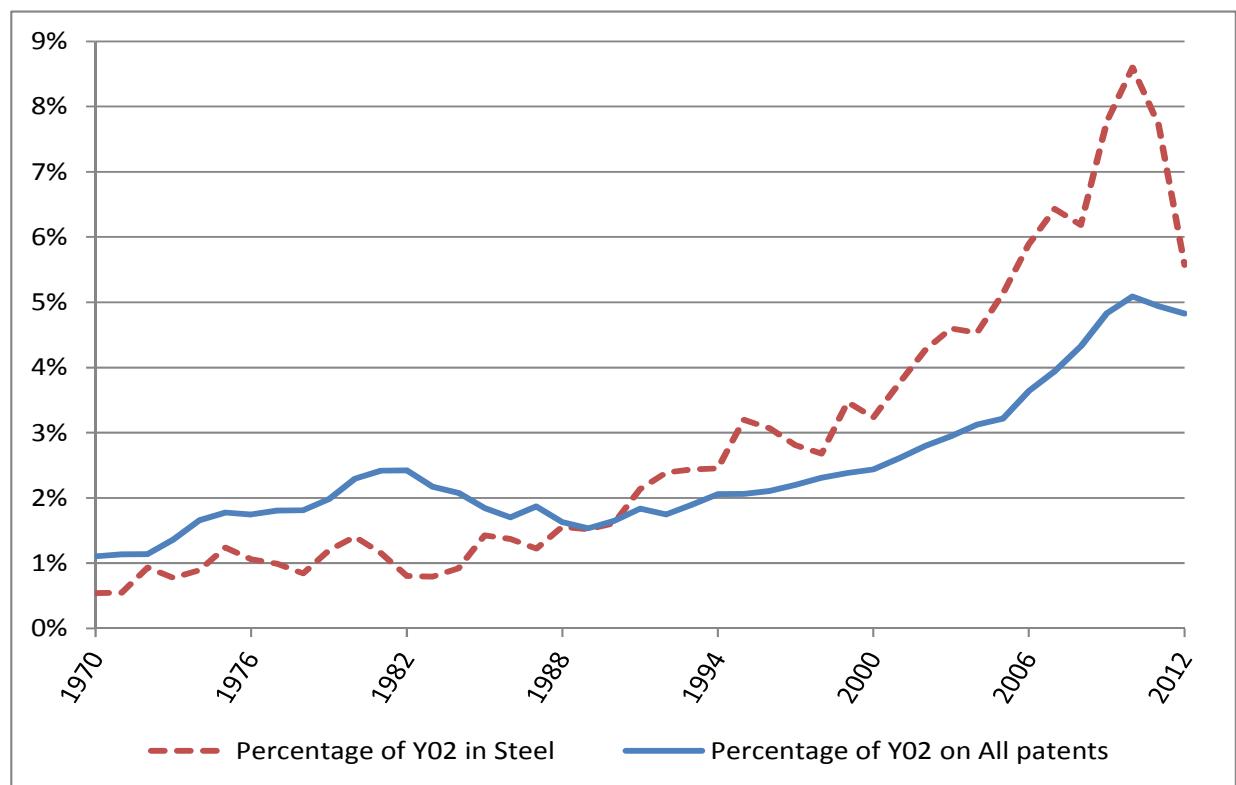

Note: Low carbon related patents are obtained through the patent tag Y02. Steel patents related to climate change mitigation result from the intersection of steel-related patents and Y02, as described in (Silva and De Carvalho, 2016[12]).

Source: (OECD, 2015[14]).

Going forward, the adoption of new and cleaner production technologies will require considerable investment - in terms of either refitting existing furnaces or investing in entirely new equipment, while possibly having to decommission existing equipment.

In a period when the steel sector still faces financial vulnerabilities, probably not all companies will be in a position to allocate sufficient resources to embark on this transformation. The technological shift entailed by the move towards "greener" steel production may therefore result in important structural changes for the steel industry. While some companies will thrive, more polluting and less efficient plants are likely to face increasing pressure to adjust.

\subsection{The importance of structural adjustment}

Facilitating resource allocation across firms and sectors of the economy is a key element of structural change and a driver of economic growth. The focus of the OECD Steel Committee's work is on promoting structural adaptation of the steel sector that would lead to more open and less distorted steel markets, resulting in a more efficient allocation of productive resources.

The steel sector has been constantly adapting, including in response to the changes described in Section 2.1. However, certain periods may require that the industry responds more quickly and/or comprehensively to structural changes. For example, the currently persisting structural imbalances, resulting from industrial characteristics as well as inefficient policy settings, require urgent action. Structural adjustment in the steel sector can also help prepare it to tackle future challenges and ensure its long-term viability.

Adjustment can take several forms. First, restructuring involving closures (exit) and new investments (entry) can result in considerable productivity gains - see OECD $\left(2017_{[15]}\right)$ for the relationship between business dynamism and productivity across selected OECD 
economies and Collard-Wexler and De Loecker $\left(2015_{[9]}\right)$ for the case of the steel industry in the United States. This includes closing assets in the steel sector and moving resources to other parts of the economy (across sectors), ensuring that more efficient companies can make new investments and less efficient companies exit the market. Likewise, the rationalisation of production units within companies may be necessary through the concentration of production in the most productive plants. Notwithstanding, these forms of adjustment can take time and offer considerable policy challenges (Rimini et al., $\left.2020_{[10]}\right)$. In an industry characterised by high barriers to entry and exit, investment expectations play a very important role, to ensure that needed change starts well in advance. Expectations about steel market developments are often not realised due to imperfect knowledge and have been clearly leaning on the optimistic side in several past episodes, resulting in over-investment.

Second, reorganising production and streamlining operations may be easier to implement. These include for example partial or temporary plant closures, limited lay-offs or tweaks in production processes that increase multi-factor productivity and may prove sufficient for a firm to become leaner and ready to respond to changing market conditions. They may nevertheless fall short of the adjustment that may be needed in response to considerable structural imbalances or significant market swings.

Third, structural adjustment is very much related to technology. Steel firms can improve efficiency and become more resilient to shocks by upgrading or replacing their steelmaking equipment and/or by shifting towards more flexible and efficient technologies. For example, the replacement of OHF by modern steelmaking technologies can significantly help increase productivity. EAF and potentially new breakthrough technologies may offer more flexibility and better environmental performance.

Fourth, structural adjustment may also be driven by changes in business structure such as consolidation through mergers and acquisitions (M\&A), or other changes in ownership (e.g. privatisation/nationalisation). For example, according to recent OECD work, M\&A activity seems to be associated with equipment closures within the resulting business group (OECD, 2020 $[16])$, which is also indicative of decisions regarding the capacity structure (i.e., whether an equipment should be shut down or new equipment installed) being taken at the group level. The direct involvement (or absence) of the State in steel production can also play an important role. While nationalisation of steel companies was used in the past as an instrument to reduce steelmaking capacity, privatisation is often associated with a rationalisation of production assets. In recent years, state enterprises have been shown to significantly contribute to increases in steelmaking capacity (Mattera and Silva, 2018 $[17]$ ).

Framework conditions and targeted policies can hinder or facilitate adjustment depending on how they are designed and implemented (GFSEC, $2017_{[18]}$ ). For example, bankruptcy legislation together with active labour market policies can facilitate the rationalisation of factors of production, while competition policy can facilitate the reorganisation of production units into efficient scale, while ensuring a level playing field that promotes business dynamism and allows the most efficient producers to strive. Transparent and efficient financial markets can also help funnel resources towards the most efficient producers and production units and technologies. Policies affecting steelmaking raw material markets, energy and other inputs can be calibrated to incentivise the development of technologies that enable the industry to better respond to changing market conditions. Incentives to upgrade existing assets towards more flexible, efficient (and cleaner) modes of production can also help the industry become leaner and better prepared for the challenges ahead. 
This paper builds on data from the newly assembled and unique OECD Steel database, developed in the context of the Steel Committee's 2019-20 work programme. This database allows combining microdata on steelmaking capacity and technology from the OECD Capacity database with financial information from Bureau van Dijk's ORBIS - see OECD $\left(2020_{[19]}\right)$ for further details. The development of this database is still work in progress, but it already provides invaluable insights into the characteristics of steel plants and steel firms and on how they evolved in the last 20 years across most of the steel producing economies in the world. While the objective is to cover all crude steelmaking units in the world that have been operating (or operated) since 2000, the underlying work is resource intensive. Therefore, the geographical coverage has been increasing over time, with a view to reach full coverage in 2021. Annex B provides the list of jurisdictions already included in the OECD Steel database.

The OECD Steel database is the most comprehensive data on crude steel production units. For each jurisdiction included in the database, it intends to cover the population of crude steelmaking production units - i.e. the OECD Steel database is being developed to cover $100 \%$ of the units and aggregate capacity of the jurisdiction. The coverage of financial information, which is available from ORBIS, is nevertheless considerably lower. ORBIS observations account for more than $20 \%(15 \%)$ of the total number of firms (steelmaking capacity) in the period 2008-2018, but there are data limitations notably up until 2005 and 2019 data are not yet available for a considerable number of companies. ${ }^{2}$ As such, the analyses of financial performance described in this paper build upon a subsample of firms and the necessary statistical methods are used to correct for potential biases (see Annex B for details). Please refer to Annex B for the ORBIS coverage of the top 30 steelmaking economies and Bajgar, et al. (2020[20]) for an overview of the coverage across different economies and sectors.

The OECD Steel database provides a wealth of information at a high level of disaggregation (equipment, plant or company), including production capacity, technology, operating status, company characteristics and financial information - Annex A provides a list of main variables and indicators used in the analyses.

A number of improvements are currently being carried out. These include for example an increase in the coverage of jurisdictions, better coverage of ORBIS in some economies (notably in North America) and the inclusion of additional financial variables (e.g. operating profits, interest rates). 
Figure 8. Units of observation in the OECD Steel database 2000-2019

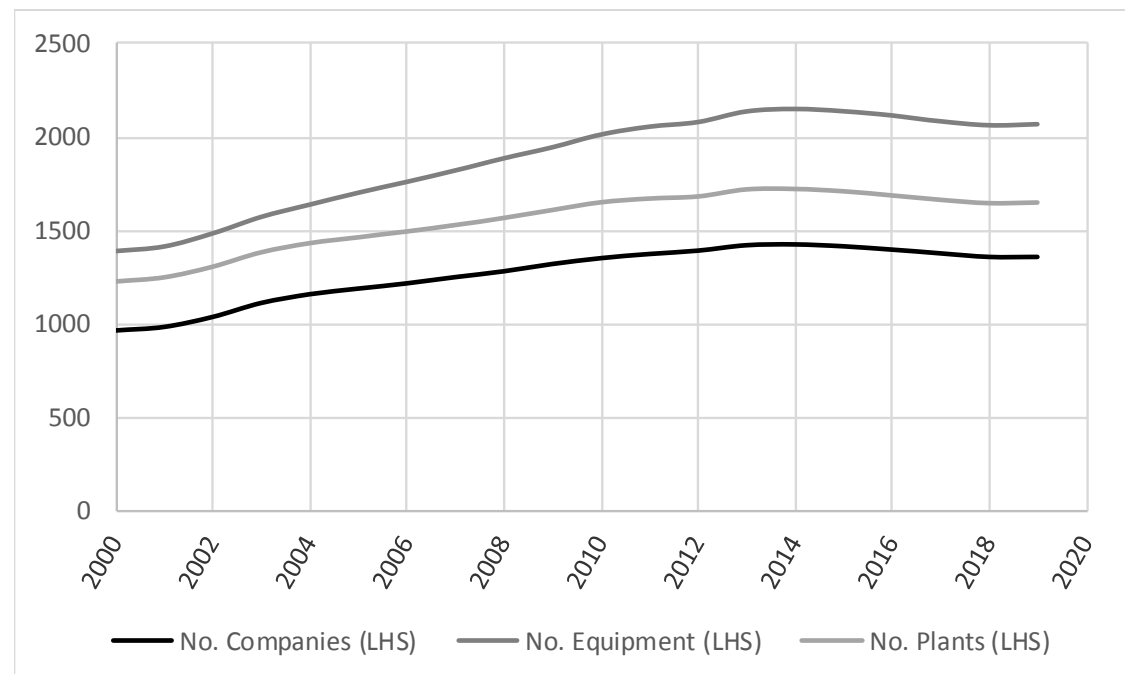

Source: OECD Steel database.

The OECD Steel database uses three levels of aggregation that reflect main units of observation: i) equipment; ii) plant; and iii) company.

- Equipment. Equipment is the most disaggregated unit of observation available. It refers to the different crude steelmaking equipment in the same Plant. The database registers individual pieces of steelmaking equipment (e.g. EAF\#1 + EAF\#2 are separate observations) insofar as detailed information is available. ${ }^{3}$

- Plant. Plant is an aggregation of crude steelmaking equipment in the same location. It can be associated with the steelmaking facilities in a given "site" (definition used in other steel databases). This unit of observation corresponds to the international definition of "Establishment". ${ }^{4}$ Please note that this definition is different from that used in the Global Forum on Steel Excess capacity (GFSEC). The GFSEC definition of plant corresponds to the OECD definition of equipment.

- Company. A Company is made up of at least one crude steelmaking plant. It can also include other types of production units not related to steel. This corresponds to the international definition of "Enterprise".

The definition of "Group" as an aggregation of different companies that have the same owner is part of ongoing work on the OECD Steel database. While a "Group" is also formally defined as an "Enterprise", the distinction will be made in the database to allow for specific analytical work regarding groups, ownership and consolidation. 


\section{The changing characteristics of steel plants and steel firms}

\subsection{Business dynamism}

Business dynamism leading to aggregate productivity growth results from wellfunctioning market entry and exit and a competitive environment where efficient firms grow and less efficient firms shrink. Business dynamism in the steel sector is relatively low. Figure 9 shows that the total turnover (additions and closures) has remained relatively stable at around $4 \%$ of the total number of steelmaking equipment since the early $2000 \mathrm{~s}^{5}$ As a means of comparison, in 2014 the churn rate of all enterprises with at least one employee was on average around $20 \%$ in the OECD area (OECD, 2017 $\left.7_{[21]}\right)$ and the churn rate of enterprises in the in the manufacturing sector ranged from $8 \%$ to $30 \%$ across OECD economies $\left(\mathrm{OECD}, 2020_{[22]}\right)$. While the turnover rate in the steel sector until 2013 was mainly driven by new entries, the number of closures has been increasing since the 200809 financial crisis resulting in the net reduction of the number of steelmaking equipment globally.

\section{Figure 9. Evolution of the number of new and closed steelmaking equipment}

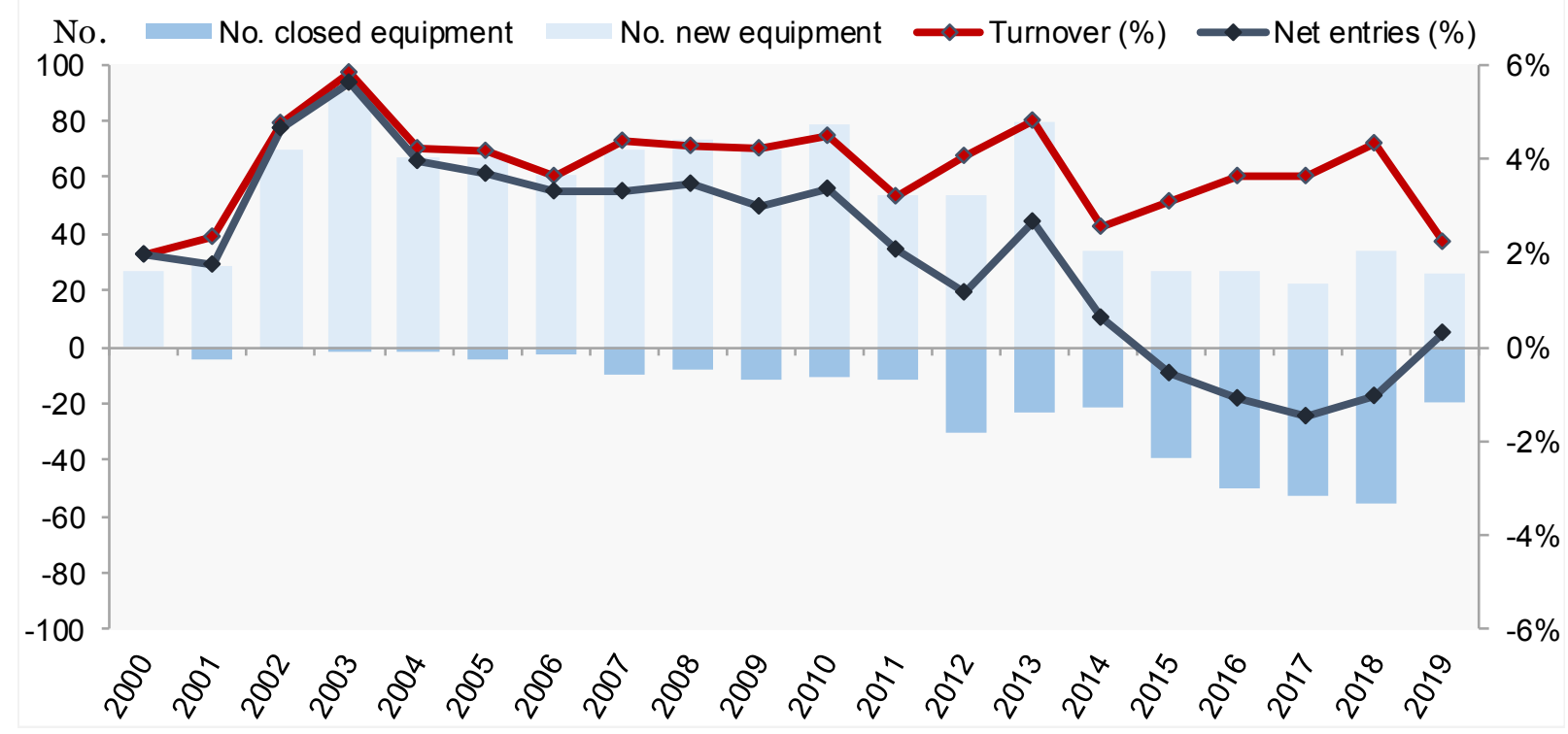

Note: The changes in capacity shown in this figure reflect only changes in capacity taking place in the economies covered by the OECD Steel database - see Annex B for the list of economies. This figure shows the number of new steelmaking equipment that started operating ("No. new equipment"), the number of equipment that was closed ("No. closed equipment") as well as the share of the sum of entries and exits in the total number of equipment ("Turnover") and the percentage of net new equipment in each year ("Net entries"). Please note that the "Turnover" statistic is different from the definition used for "churn rate" because of the level of aggregation - equipment instead of plant or company - and is therefore not directly comparable. Source: OECD Steel database.

The low business dynamism in the steel sector has nevertheless resulted in non-negligible changes in steelmaking capacity. Capacity additions were common during the expansionary 2000s and continued after the 2008-09 financial crisis at around $100 \mathrm{mmt}$ of gross capacity additions per year up until 2013, followed by a period when these were halved to around $40 \mathrm{mmt}$ per annum up until 2019 (Figure 10). Capacity closures 
intensified gradually after the 2008-09 financial crisis and in particular after 2014, when total gross closures fluctuated between $40 \mathrm{mmt}$ and $60 \mathrm{mmt}$ per year. This resulted in annual net capacity reductions between 2015 and 2018, for the first time in two decades.

Figure 10 shows the decomposition of net capacity changes into gross capacity additions resulting from new companies (entry) or existing companies expanding capacity (expansion), and gross closures resulting from closures of the entire company (exit) or partial closures within a company (contraction). Interestingly, while most of the gross capacity additions result from incumbent firms expanding capacity, gross capacity reductions since 2015 reflect firm exit to a larger extent than before, when partial closures accounted for the lion's share of capacity reductions.

\section{Figure 10. Changes in capacity 2000-2019}

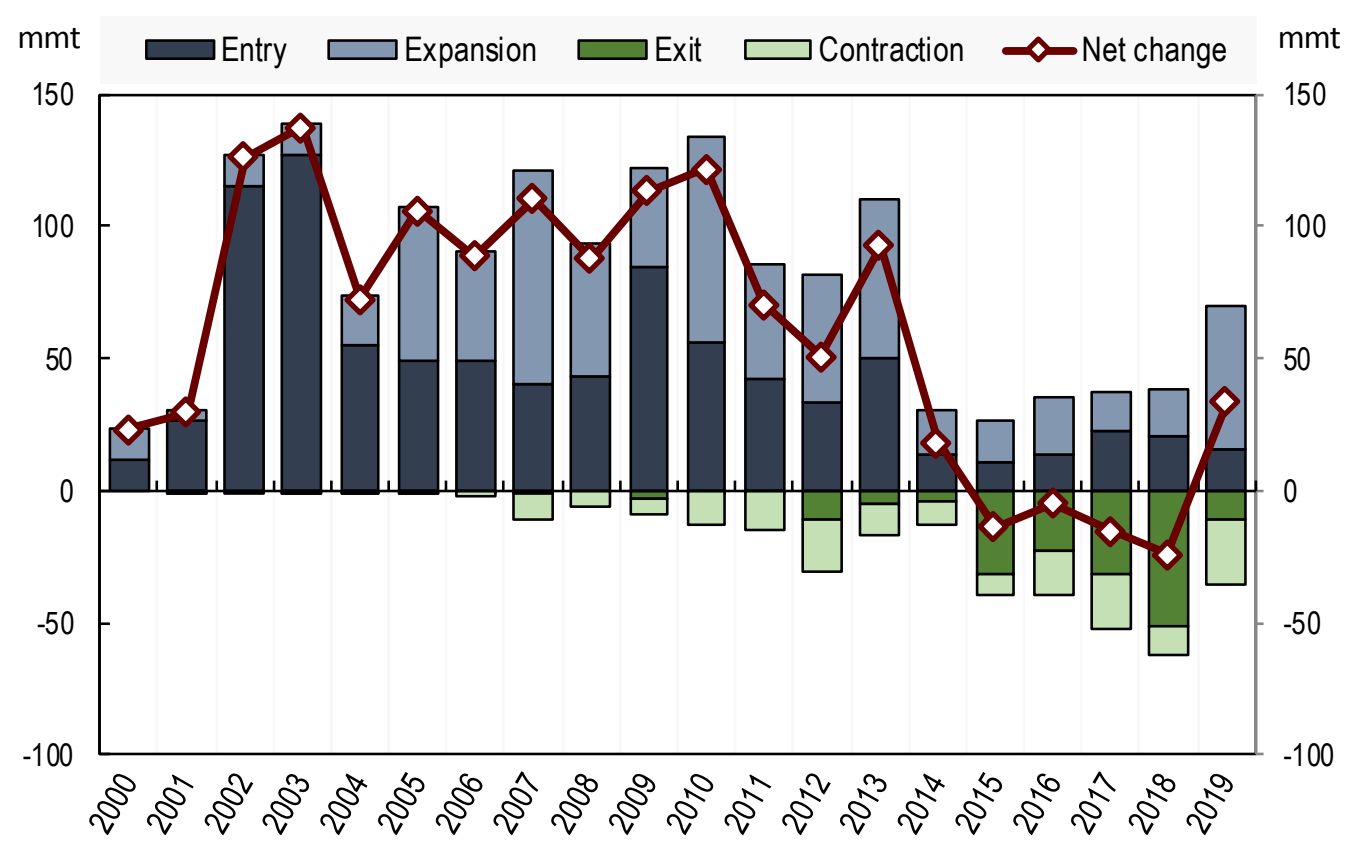

Note: The changes in capacity shown in this figure reflect only changes in capacity taking place in the economies covered by the OECD Steel database - see Annex B for the list of economies. "Entry" reflect new steelmaking capacity of entrants (new firms producing crude steel), "Expansion" denotes firms that have deployed new capacity in addition to already existing equipment, "Exit" reflect the capacity of companies that closed and no longer have any business in crude steel production, and "Contraction" refers to partial closures (i.e. the company continues to operate with other equipment). All values are in $\mathrm{mmt}$.

Source: OECD Steel database.

These changes were necessarily different across jurisdictions (Figure 11), as an outcome of market (and non-market) incentives to expand, reduce or replace capacity. To better understand the changes in aggregate gross additions and closures and get a better grip on the underlying incentives, a detailed analysis of the characteristics of the equipment and plants, as well as the firms investing in new capacity and those closing capacity is warranted. 
Figure 11. Changes in capacity across economies

Total gross and net changes for the period 2009-2019

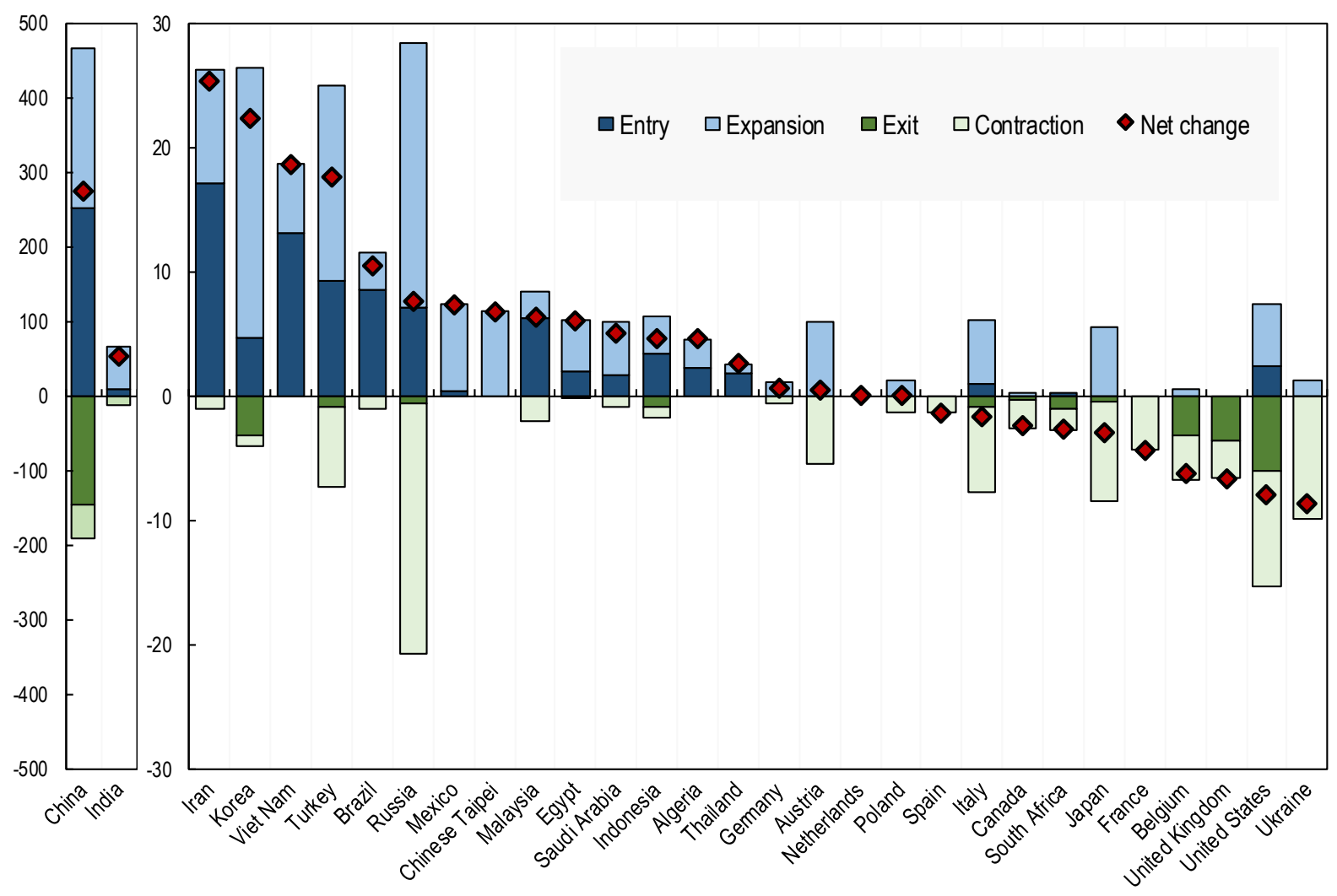

Note: In this figure, gross additions and closures respectively represent the sum of capacity additions and closures during the reference period. The marker indicating net changes represent the difference between the two gross measures - i.e. the net change over the period. The figure shows the top 30 steel producing economies ranked by the net change in capacity during the reference period. Source: OECD Steel database.

\subsubsection{New investments and growth}

Figure 12 .A shows that while $35 \%$ of new capacity additions originate in new entrants (companies investing in new capacity for the first time), well-established incumbents account for the lion's share of new crude steelmaking capacity investments $(65 \%)$. Moreover, companies that invest in new capacity are larger than other companies (Figure 12.B), with the average size of companies investing in new capacity standing at around $7.7 \mathrm{mmt}$, more than double the average size of companies that do not invest in new capacity $(3.3 \mathrm{mmt})$. This result highlights the importance of economies of scale in the steel sector. 


\section{4}

THE CHANGING CHARACTERISTICS OF STEEL FIRMS

\section{Figure 12. The vintage and size of firms investing in new capacity}

A. Company vintage

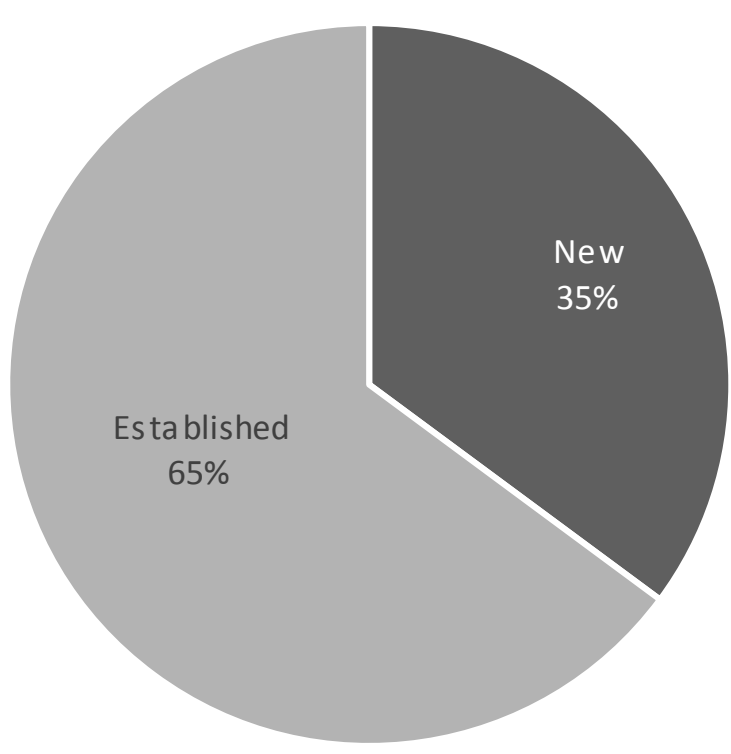

B. Company size

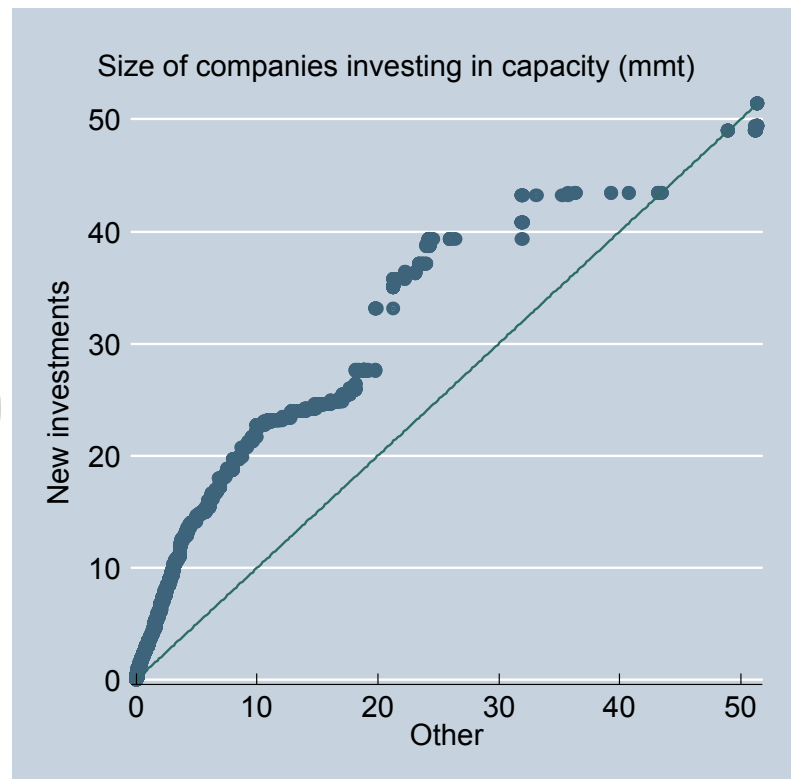

Note: Panel A. Company vintage, distinguishes between investments made by companies that have started producing crude steel for the first time (New) compared to investments made by companies that were already operating crude steelmaking equipment (Established). Panel B. Company size, shows two distributions using a quantile-quantile plot. This type of chart contrasts values in the same quantile of two different distributions. Therefore, values above the symmetry line $(y=x)$ indicate that the distribution labelled in the vertical axis dominates the distribution labelled in the horizontal axis. The reverse is true for values below the symmetry line. "Other" refers to companies that have not carried out new investments in steelmaking capacity. Source: OECD Steel database.

Taken together, the data on size and vintage of companies investing in new capacity would suggest that incumbents in the steel market continue to grow larger and take larger portions of the market share.

Moreover, data shows that older plants are less indebted than younger firms (Figure 13), suggesting that set up costs in the steel sector can be significant and continue to weigh in on the financial health for several years. Higher set up costs can also help explain the weak dynamism of the sector that has relatively low entry and exit rates. 
Figure 13. Distribution of indebtedness by plant age, 2000-2019

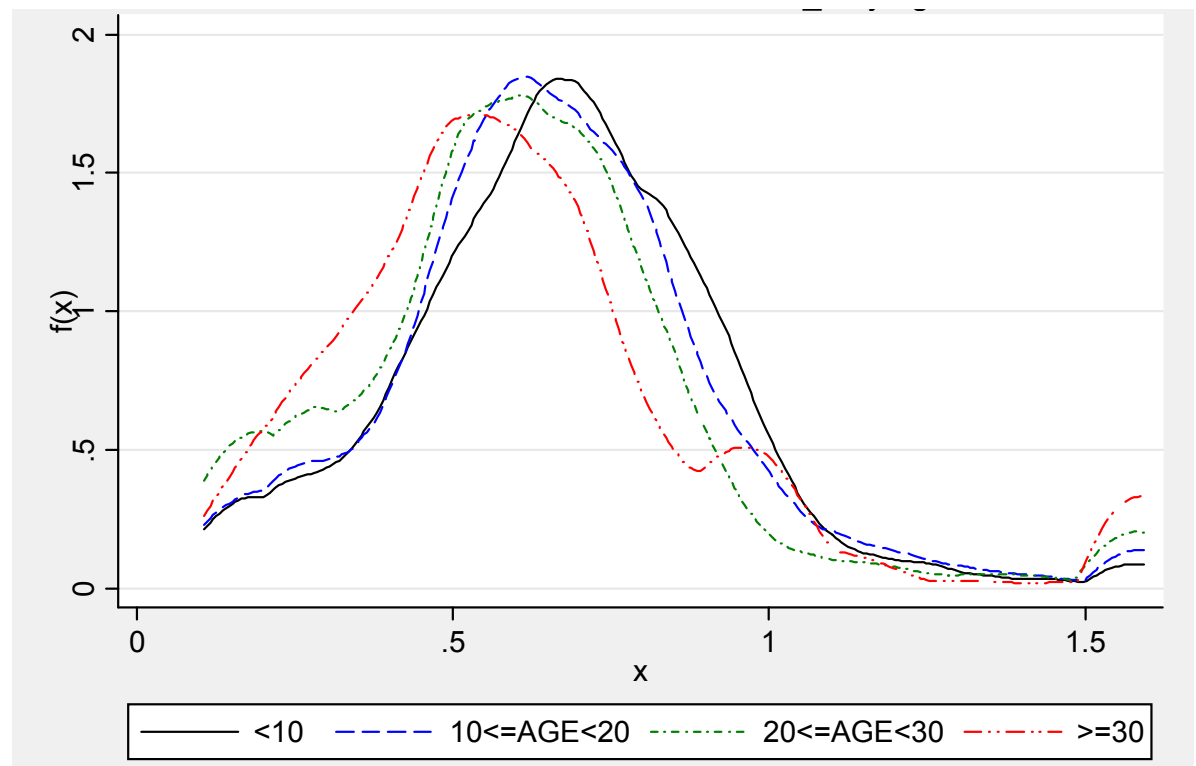

Note: This figure plots the distributions indebtedness (Panel B) for plants with less than 10 years (solid black line), plants that have between 10 and 20 years (dashed blue line), plants that have between 20 and 30 years (short-dash green line) and plants with more than 30 years (long-dash red line) using kernel density estimates. The kernel density estimate gives an approximation of the probability density function of a given distribution - up to a given point $\mathrm{x}$ in the horizontal axis, the area under this function provides the percentage of observations that have values that are lower or equal to $\mathrm{x}$. The total area below the curve for each year equals one. Please refer to Annex A for the definitions of the variables used.

Source: OECD Steel database.

Business dynamism is also characterised by the extent to which firms are able to expand or contract. Steel companies that have grown more rapidly since 2000 are typically larger, younger, less indebted and more profitable. Fast-growing plants are also those investing in either BOF or IF technology. Figure 14 illustrates the differences in the average capacity growth rates across different technologies, ${ }^{6}$ while charts with data for other relevant variables are available in Annex B. 


\section{Figure 14. Firm growth}

Average annual firm growth, 2000-2019

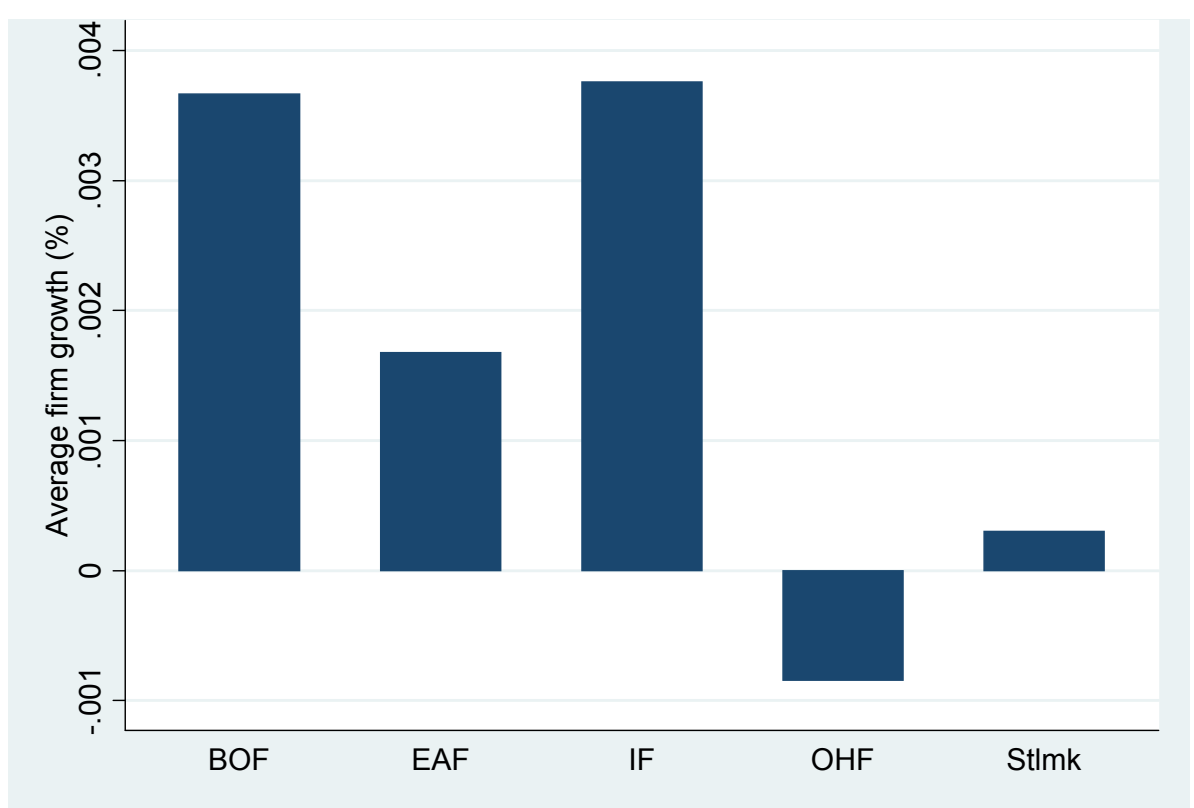

Note: This figure plots the average annual growth in steelmaking capacity (at the company level) for different categories across all years and all firms. The growth rates are very small because the vast majority ( $84.2 \%)$ of steel companies did not invest during the period 2000-2019.

Source: OECD Steel database.

\subsubsection{Capacity closures}

Part of the low dynamism in the steel sector results from relatively low number of closures. Barriers to exit in the steel sector are important and key characteristics of plants closing capacity are discussed in Rimini et al. $\left(2020_{[10]}\right)$. Findings suggest that the likelihood of closure is greater for smaller and single-plant firms, highlighting the important of sunk costs as structural barriers to exit. Technology was also found to be important, with overall higher probability of exit plants using BOF technology.

This section complements those analyses by providing new information on how financial performance may affect closures. Interestingly, the data suggests that financial performance and closures are not related in an obvious fashion. Figure 15 shows the estimated probability of closure for different quantiles of the distribution of profitability and indebtedness. While it is difficult to distinguish any particular differences, regression results controlling for size, technology and financial performance, reject any statistically significant relationship between financial performance and closure. Some of the curves even contradict intuition, as one would have expected the Kaplan-Meier closure curve to be higher for firms with lower profits (black in Figure 15 below) and lower for firms with higher profits (yellow in Figure 15 below).

These findings seem to suggest that the market selection mechanism is not working and that plants with worse financial performance (likely associated with lower efficiency) are allowed to remain in operation, in detriment of better performing firms. This may point towards non-market factors, such as government interventions, that may be distorting steel markets. Further more detailed analysis should confirm these tentative conclusions however. 
For example, support to ailing firms and/or "national champions", may to some extent, explain the counter-intuitive higher closure probability of higher profit steel firms compared to lower profit steel firms. Again, a more precise study is warranted to better understand the relationship between profit margins and closure. Government interventions may also explain why the steel plants with the lowest debt have the highest default rates.

\section{Figure 15. Financial performance and the probability of closure}

A. Profitability (profit margin)

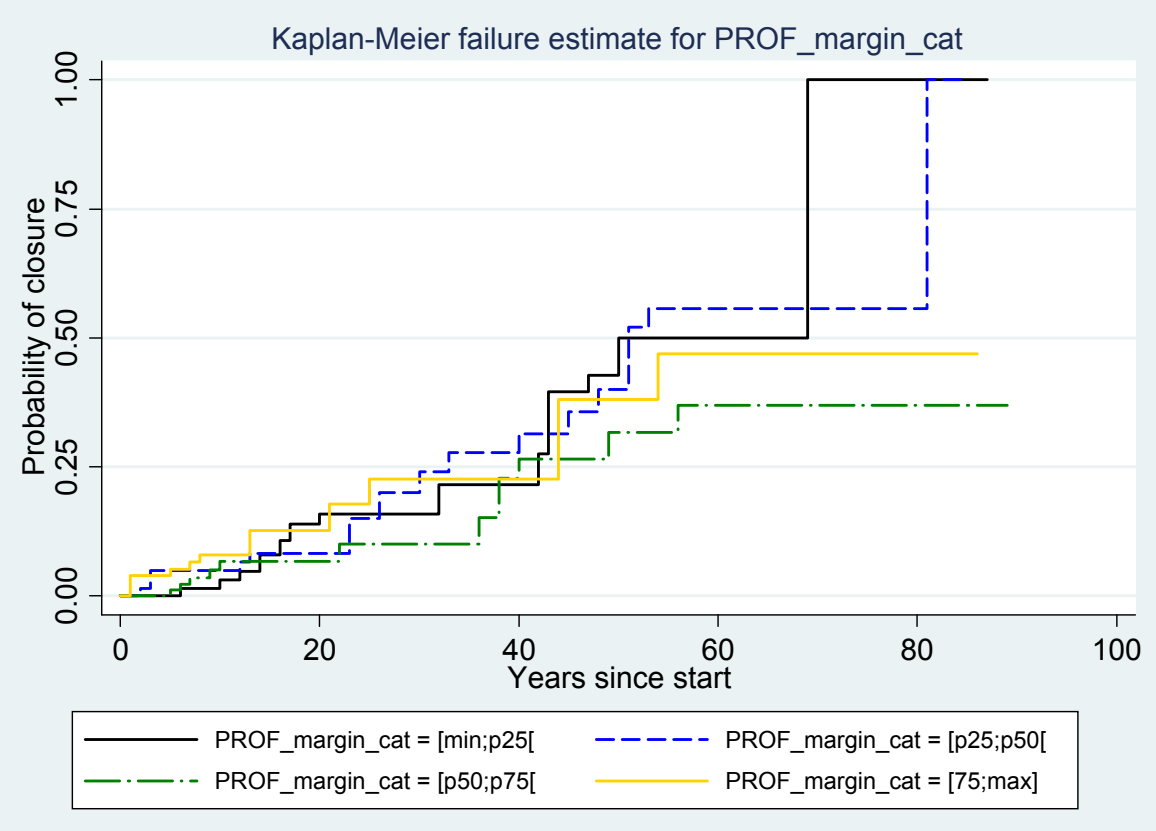

B. Indebtedness (asset-based)

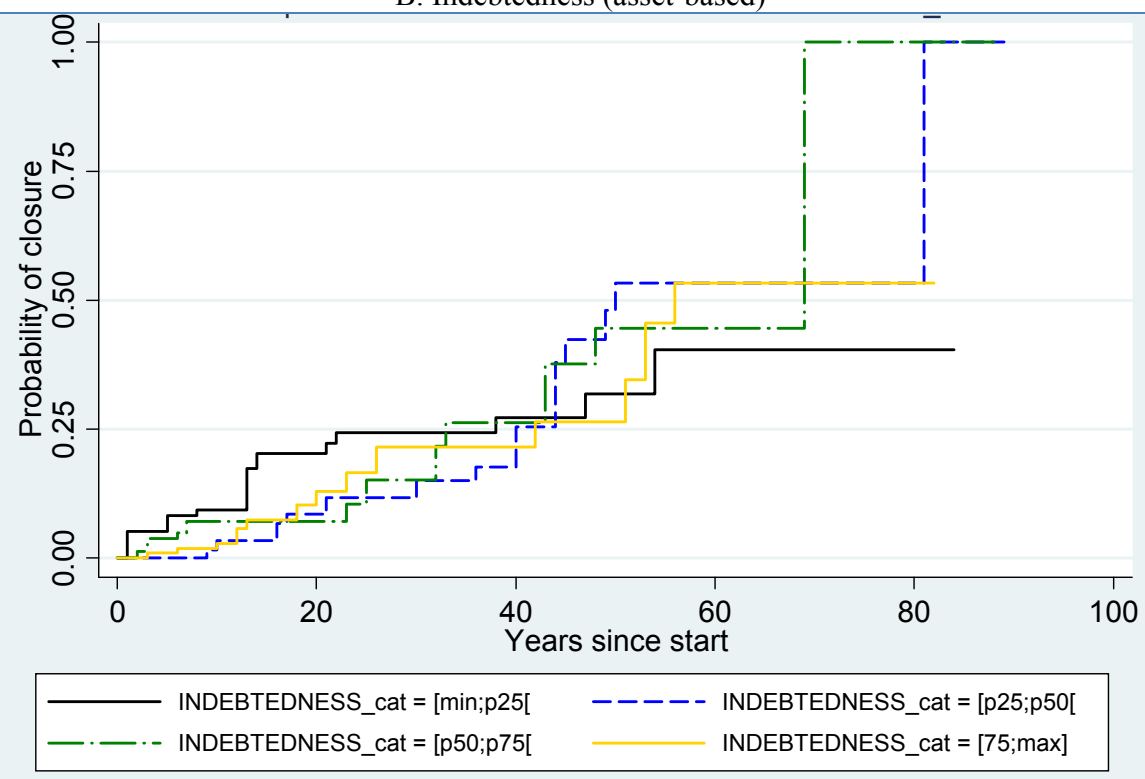

Note: The Kaplan-Meier failure curve estimates the probability of closure over time by computing the number of units closed over those remaining in operation at each point in time in the sample. Different lines represent the probability of closure for units in different quantiles of the distribution of the relevant indicator. Please refer to Annex A for the definitions of the variables used.

Source: OECD Steel database 
New data from the OECD Steel database also shows that equipment that are part of an international group are less likely to close (Figure 16). This is partially explained by the ability to reallocate financial and other resources within the groups. Admittedly, it could be argued that the possibility to optimise production in the group should result in more closures as resources are shifted away from the least to the most productive units. However, data hints that reallocation may take the form of financial transfers (and possibly pricing mechanisms internal to the group) that sustain less productive units at the costs of more productive segments. ${ }^{7}$ Another explanation resides in the ability to access to external finance - see e.g. Dewenter, Novaes and Pettway $\left(2001_{[23]}\right)$ - , which is facilitated by the group's size and thus the ability to use other assets as collateral, as well as by the international dimension that allows tapping into different sources of finance across economies. These results are in line to the findings for multi-plant firms by Rimini et al. $\left(2020_{[10]}\right)$.

Figure 16. International groups and the probability of closure

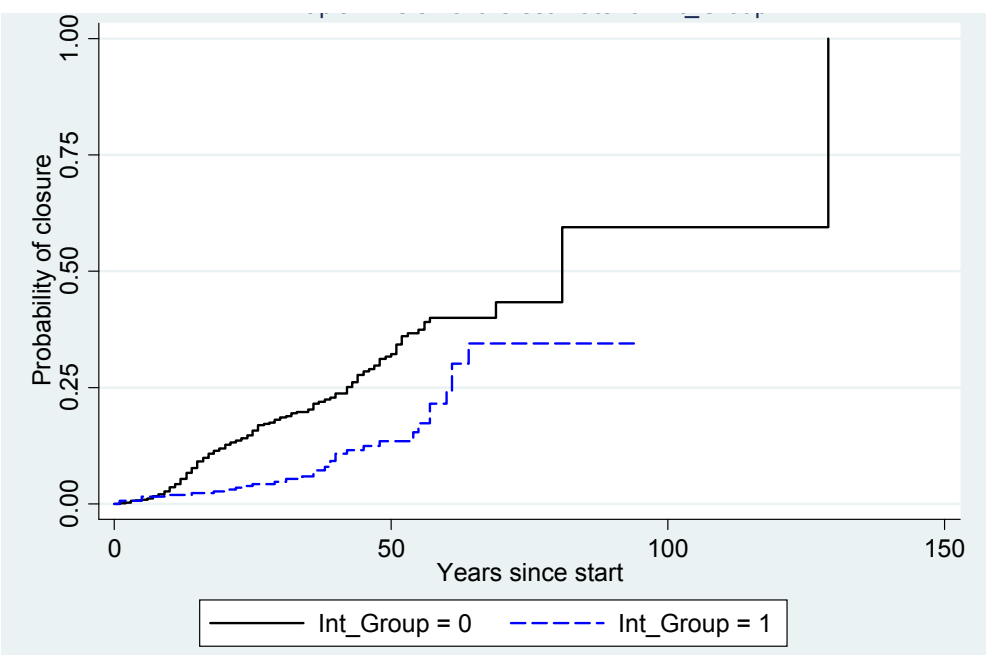

Note: The Kaplan-Meier failure curve estimates the probability of closure over time by computing the number of units closed over those remaining in operation at each point in time in the sample. "Int_Group" is a binary indicator of whether a plant belongs to an international group (1) or not (0). Please refer to Annex A for the definitions of the variables used.

Source: OECD Steel database.

\subsection{Steelmaking capacity and financial performance}

The cyclical nature of the steel sector is reflected in the evolution of the profitability of steelmaking plants. ${ }^{8}$ Figure 17.A shows that despite an overall drop in profits levels, which declined from a median (across companies) fluctuating around EUR 15 million in 20002002 to around EUR 5 million during the period 2006-2015 (with profits even becoming null in 2009 and in 2015), the size of steelmaking plants had continued to grow steadily until 2014. Profits have however never again reached the levels attained during the expansion experienced in the mid-2000s. The consequent long-spell of subdued financial performance is likely a reflection of underlying persistent excess capacity. In fact, data suggest that profits picked up gradually (albeit modestly) since 2016, which is about when capacity closures started to intensify (see Figure 9 above). This highlights the importance of restructuring the industry to address the overcapacity challenge and ensure the long-term sustainability of the industry. 
In addition, imperfect and incorrect foresight combined with the lead-time required between the planning of new capacity and its effective deployment may explain the decline in profits per mmt experienced in 2006 (before the 2008-09 financial crisis), given that new capacity had continued to come on stream.

Figure 17. Evolution of profits and capacity, 2000-2019

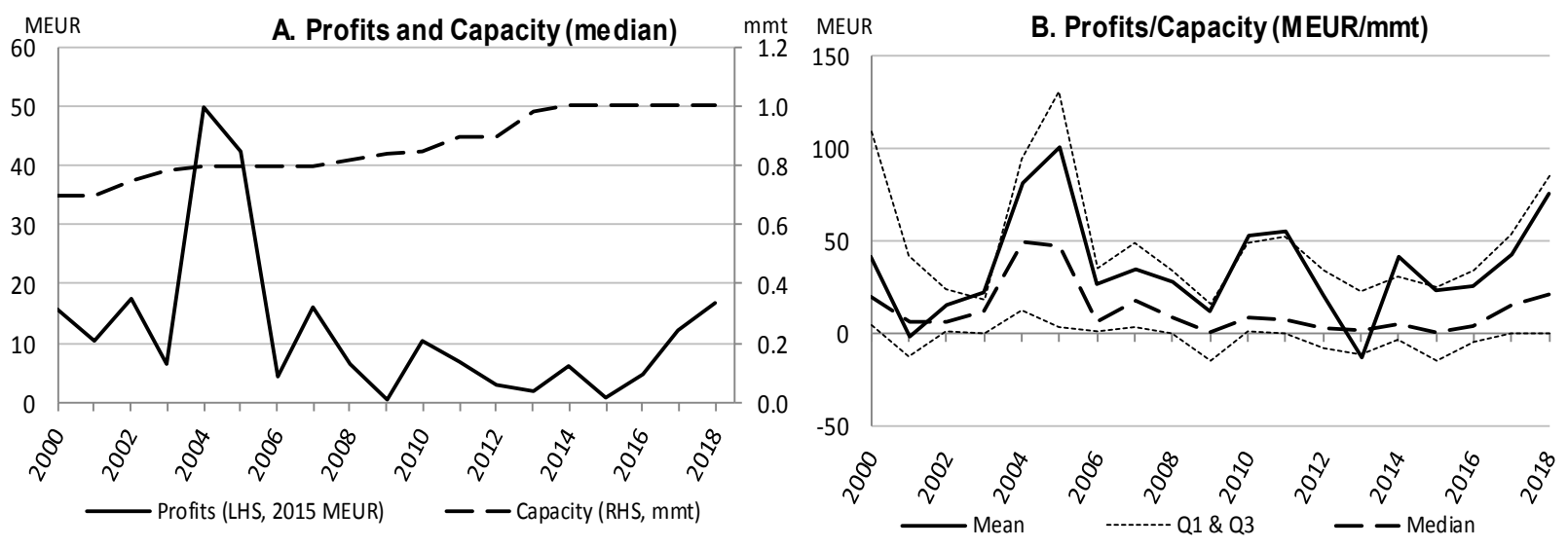

Note: Profits are shown as million euros (MEUR) and capacity in million metric tonnes. Median capacity in the left panel reflects the median size of the steelmaking plant. Please refer to Annex A for the definitions of the variables used.

Source: OECD Steel database.

There are also significant differences across economies and plants. Figure 18 illustrates the differences across the largest steelmaking economies for which data are available and in selected years. The median profit/loss in 2018 ranged from EUR 207 of profits per metric tonne of steelmaking capacity in the United States to a median loss of EUR 134 per tonne in Brazil. 
Figure 18. The profitability of steelmaking capacity varies across years and geographies

Median profitability (MEUR/mmt) in selected years and economies
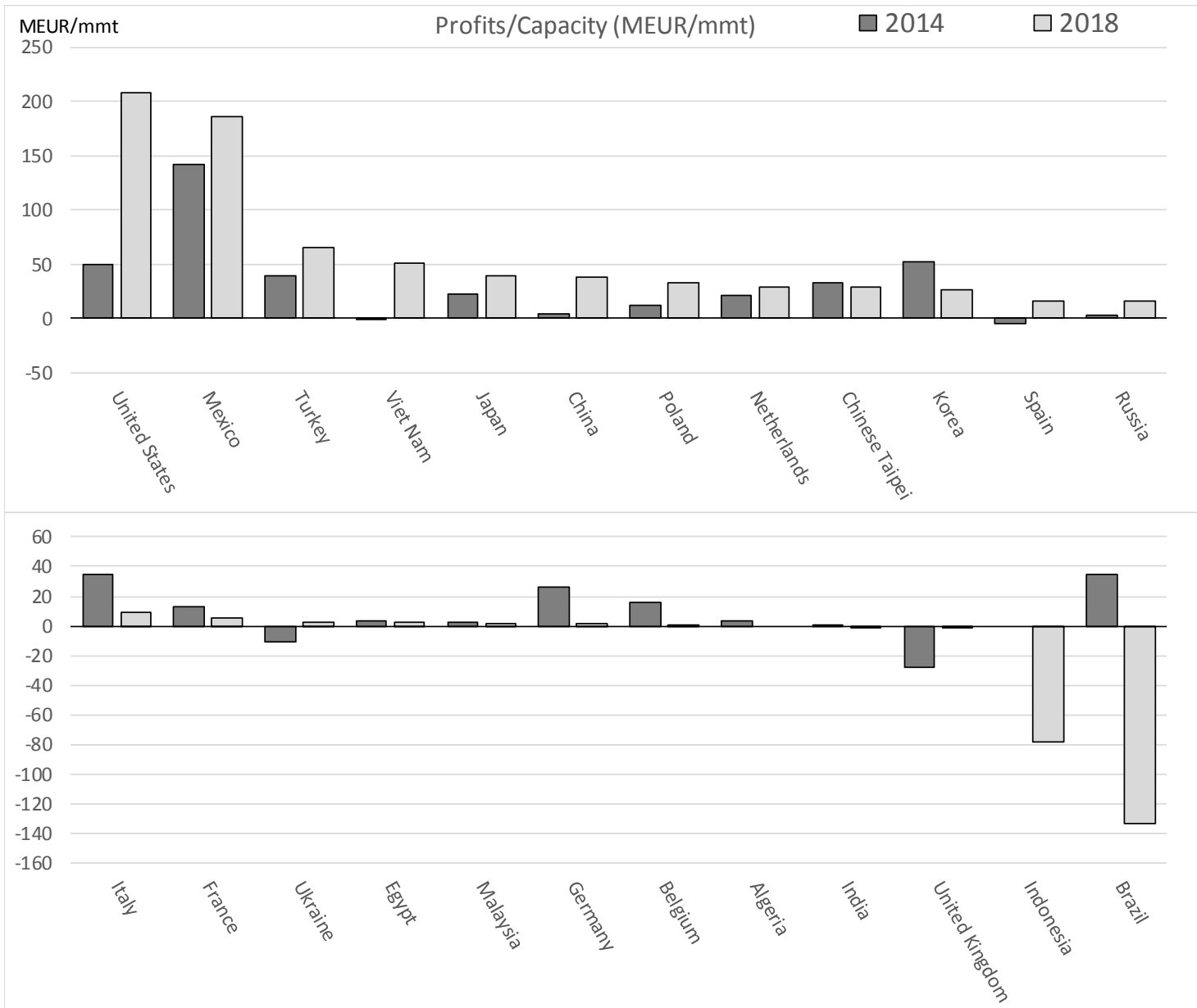

Note: The figure include 24 economies out of the top 30 steel economies (in terms of steelmaking capacity), for which plant financial information are available in the selected years. The years were chosen to reflect the latest available information with quality (2018) as well as the year with the best ORBIS coverage (2014) — see Section 3. for details on the database coverage. Please refer to Annex A for the definitions of the variables used. Source: OECD Steel database.

Figure 17.B above shows considerable heterogeneity across plants. While $25 \%$ of the steel plants analysed earned more than EUR 52 per tonne in 2018, about 25\% sustained losses. The steel sector seems to be characterised by a relatively high share of lossmaking firms (more than 25\% since the 2008-09 financial crisis), many of which remain the same over the years.

In fact, several plants appear to be recurrently in financial difficulties as shown by Table 1 . About 3.2\% of all plants exhibit persistent losses for six consecutive years, 9\% maintain unsustainably low levels of liquidity. Moreover, about $6.9 \%$ present recurring solvency issues and 5.2\% maintain unsustainably high levels of indebtedness for six years in a row. This is in line with the existence of high barriers to exit (Rimini et al., 2020 [10]), which prevent (or discourage) consistently lossmaking firms from closing. 
Table 1. Persistent poor financial performance, 2000-2019

\begin{tabular}{|l|c|c|c|c|c|c|}
\hline Indicator & $\mathbf{1}$ year & $\mathbf{2}$ years & $\mathbf{3}$ years & $\mathbf{4}$ years & $\mathbf{5}$ years & $\mathbf{6}$ years \\
\hline Profit/Capacity $(<0)$ & $50.6 \%$ & $28.1 \%$ & $15.6 \%$ & $9.2 \%$ & $5.4 \%$ & $3.2 \%$ \\
\hline Indebtedness $(>1)$ & $58.7 \%$ & $35.6 \%$ & $21.8 \%$ & $13.5 \%$ & $8.1 \%$ & $5.2 \%$ \\
\hline Liquidity $(<1)$ & $68.4 \%$ & $45.8 \%$ & $31.1 \%$ & $21.4 \%$ & $14.2 \%$ & $9.0 \%$ \\
\hline Solvency $(<20)$ & $62.5 \%$ & $38.4 \%$ & $23.9 \%$ & $15.7 \%$ & $10.7 \%$ & $6.9 \%$ \\
\hline
\end{tabular}

Note: The table shows the percentage of plants that have $n$ consecutive years of losses, high indebtedness, low liquidity or solvency. Please refer to Annex A for the definitions of the variables used. Source: OECD Steel database.

\subsection{Labour adjustments}

In the steel sector, part of the adjustment seems to rely on labour as well. Data on employment are scarce, but available figures for a subsample of plants suggest that the median number of workers per mmt has fluctuated over time, with spikes in 2003-04 and 2010 (Figure 19). In 2018, the median plant had about 1600 workers per mmt of capacity. Automation and digitalisation are likely to have played a role by increasing labour productivity, but most of the variation over time is likely to be associated with differences in the technology of new installed capacity and capacity closed. Figure 20 illustrates the differences in labour intensity across technology and shows that EAF technology is the least labour intensive, followed by BOF. OHF and IF technologies are considerably more labour intensive than the most common steelmaking technologies.

Figure 19. Evolution of labour intensity, 2000-2019

Number of workers per mmt of capacity, 2000-2018

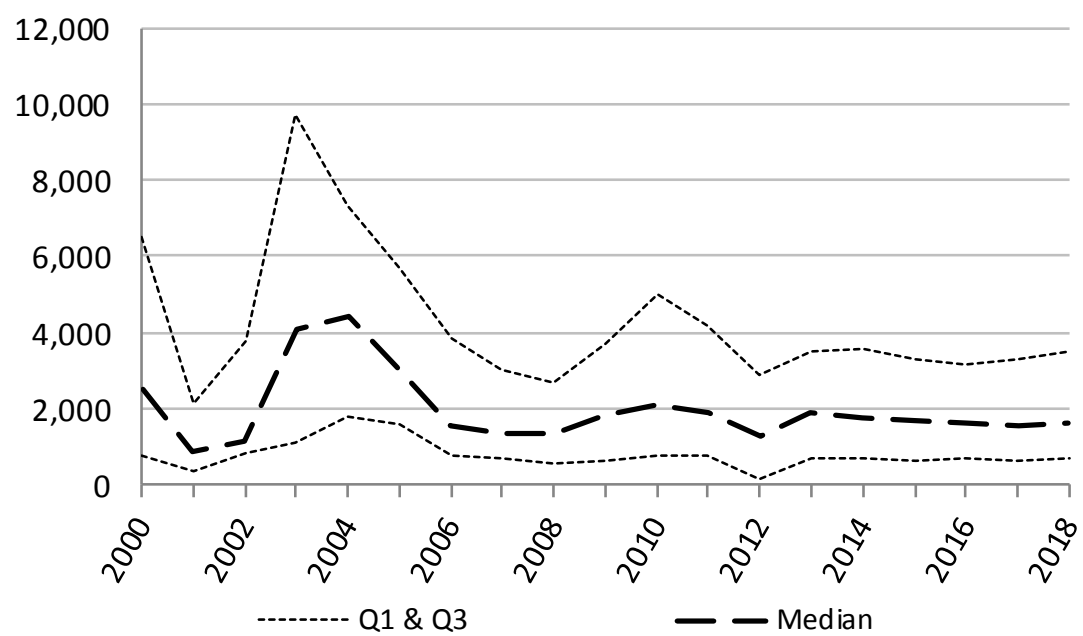

Note: Please refer to Annex A for the definitions of the variables used. Source: OECD Steel database. 
Figure 20. Labour intensity by technology, 2000-2019

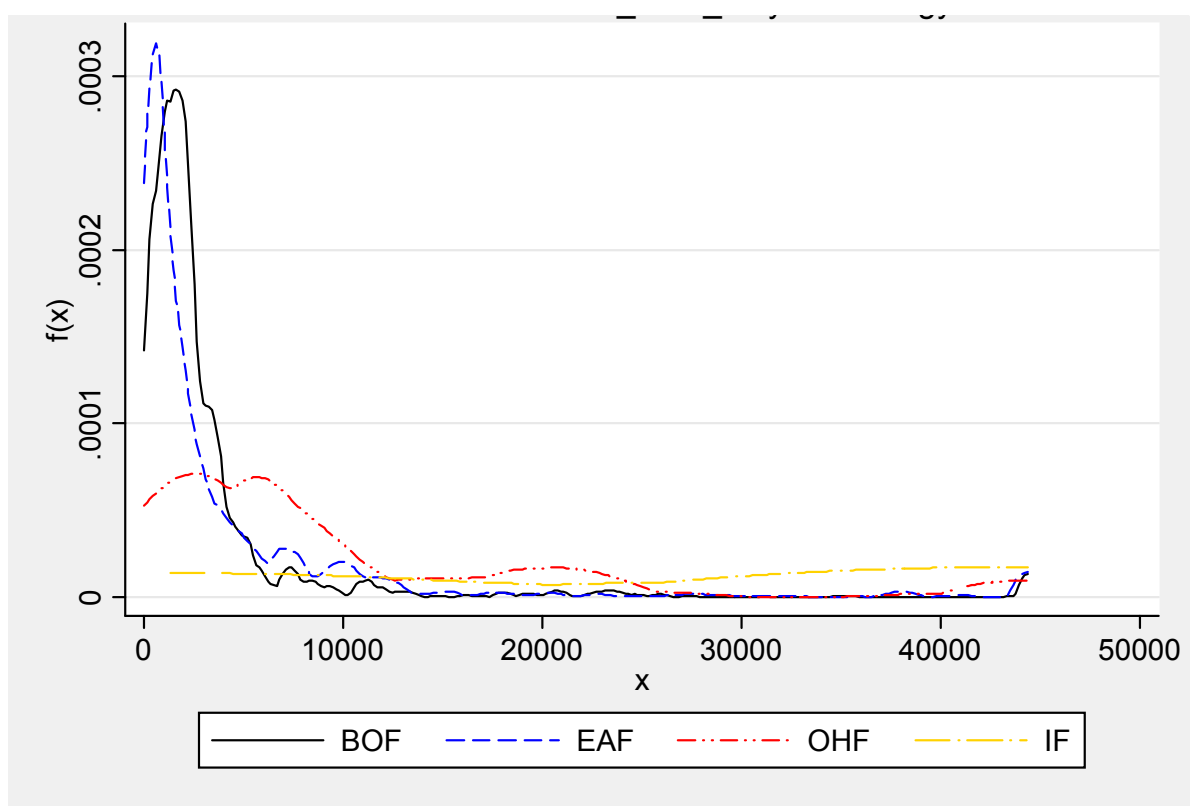

Note: This figure plots the distributions of labour intensity for BOF (solid black line), EAF (dashed blue line), OHF (dash-dot red line) and IF (dash-dot yellow line) using kernel density estimates. The kernel density estimate gives an approximation of the probability density function of a given distribution - up to a given point $\mathrm{x}$ in the horizontal axis, the area under this function provides the percentage of observations that have values that are lower or equal to $\mathrm{x}$. The total area below the curve for each year equals one. Please refer to Annex A for the definitions of the variables used.

Source; OECD Steel database.

\subsection{Performance of steelmaking technologies}

Steelmaking technology drives a number of differences across plants. For example, plants with predominantly BOF equipment are overall more profitable than firms using EAF technologies (Figure 21.A). However, BOF are more likely to incur liquidity issues and exhibit relatively higher levels of indebtedness, possibly because of higher set up costs see Annex B for additional data on financial performance by technology. Financial performance within these technologies is very heterogeneous. For example, a more detailed comparison of the profitability of BOF and EAF plants shows that very profitable EAFs are more profitable than very profitable BOFs (Figure 21.B). However, for plants yielding lower profits and those exhibiting losses, BOF technology is associated with better financial performance. ${ }^{9}$ 
Figure 21. Profitability: BOF vs EAF, 2000-2019

A. Evolution of median profit margin

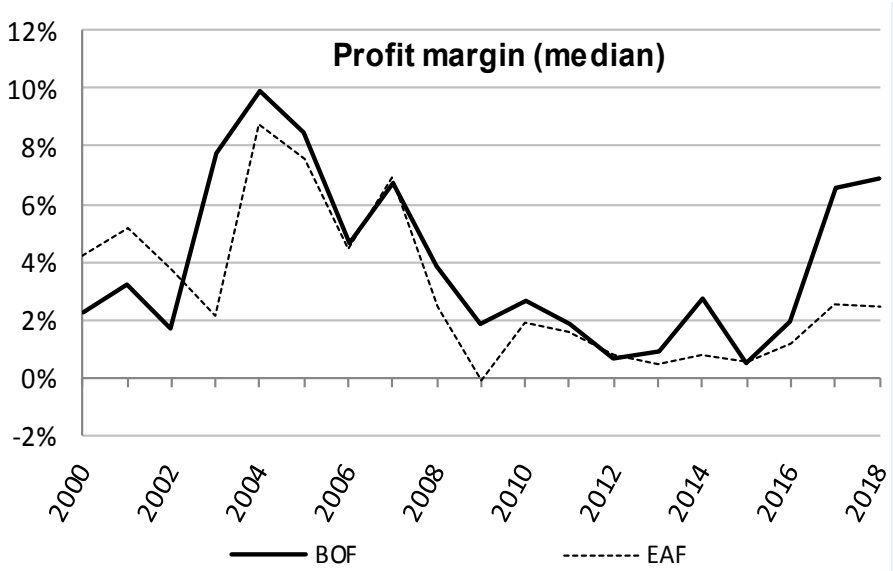

B. Comparison of the profitability distribution

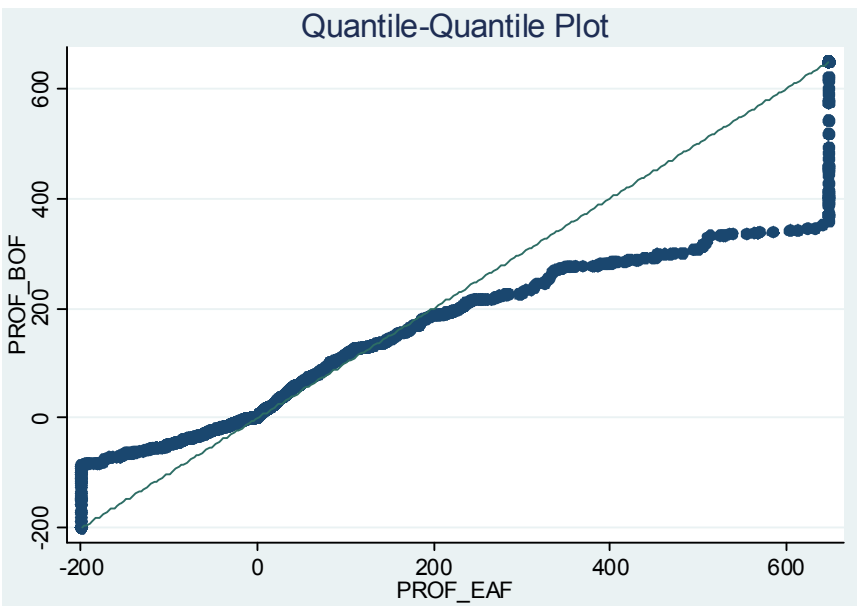

Note: Panel B compares the distribution of profits per mmt of BOFs ("PROF BOF") with that of EAFs ("PROF_EAF") using a quantile-quantile plot. This type of chart contrasts values in the same quantile of two different distributions. Therefore, values above the symmetry line $(\mathrm{y}=\mathrm{x})$ indicate that the distribution labelled in the vertical axis dominates the distribution labelled in the horizontal axis. The reverse is true for values below the symmetry line. Please refer to Annex A for the definitions of the variables used.

Source: OECD Steel database.

Despite EAFs being often argued to provide higher flexibility to adjust production to changing market conditions (Silva and de Carvalho, 2016[6]), a preliminary analysis comparing the financial performance by technology in different time periods of time shows that plants using BOF equipment are overall more profitable. The analysis also shows that the relevant BOF plants are more indebted than plants using EAF technologies in all periods of time. ${ }^{10}$

Differences in financial performance by technology are likely explained by raw material prices and economies of scale, given that BOF plants tend to be increasingly large (Figure 22). While the average size of plants increased across all technologies since 2000, BOF plants seem to have grown particularly large, with the average BOF plant's capacity (including plants with several steelmaking equipment) amounting to more than $5 \mathrm{mmt}$ in 2019, compared to slightly more than $1 \mathrm{mmt}$ in the case of EAFs. Investments in large production facilities in Asia help explain these figures. ${ }^{11}$ 
Figure 22. Evolution of the average size of steelmaking plants by technology, 2000-2019

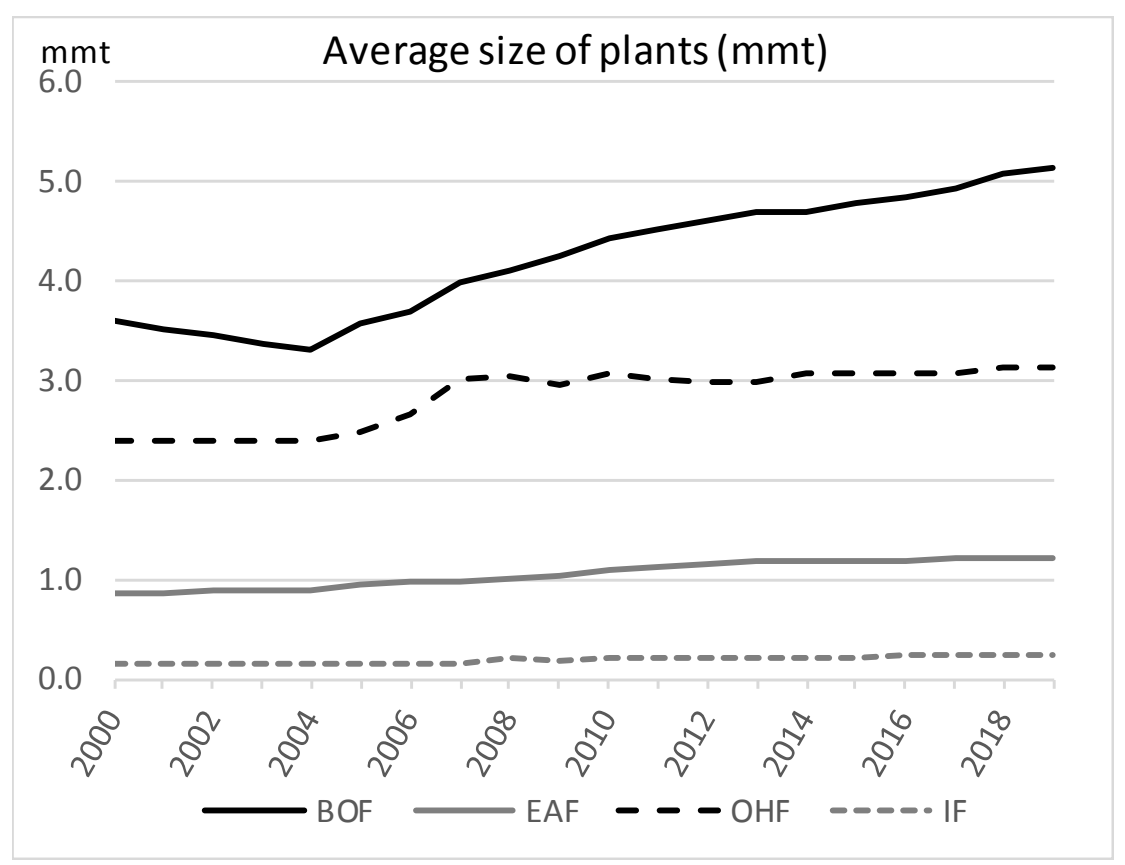

Source: OECD Steel database.

New investments in steelmaking capacity since 2000 were predominantly in EAF technology (Figure 23.A), which accounted for more than half of the total number of investments. ${ }^{12}$ About a third of capacity investments were in BOF equipment while interestingly almost $6 \%$ of new investments were in IF technology. ${ }^{13}$

The flexibility to adjust production provided by IF and to some extent by EAF technologies could explain their appeal when it comes to decide on the technology of new production capacity. This is of course notwithstanding important considerations regarding the proximity to and availability of raw materials and other key inputs for steel production using the different technologies. The local availability (and the relative prices) of highgrade iron ore, vis a vis the scrap reservoir and the development of the recycling industry, as well as the comparison between coking coal and electricity can significantly affect the choice of technology. Restrictions to trade in steelmaking raw materials also have the potential to affect the choice of technology.

Comparing the importance of each technology in both new equipment and closures, the share of IF in the number of new investments (5.7\%) and of OHF in the number of closures (7.3\%) are worth noticing (Figure 23.B). While the importance of IF technology in global capacity increased from $0.4 \%$ in 2000 to $0.7 \%$ in 2019 , the share of OHF capacity declined from $2.6 \%$ to $0.4 \%$ in the same period.

BOF and EAF remain the predominant technologies in the steel sector. Nevertheless, despite the larger number of new EAF equipment and lower number of EAF closures (when compared to BOF), the larger size of BOF equipment translates in the increasing share of BOF technology in global capacity: from $58.9 \%$ in 2000 to $67.2 \%$ in 2019 . Conversely, the share of EAF capacity declined from $38 \%$ in 2000 to $31.4 \%$ in 2019. 
Figure 23. Predominant technology in new capacity investments and closures

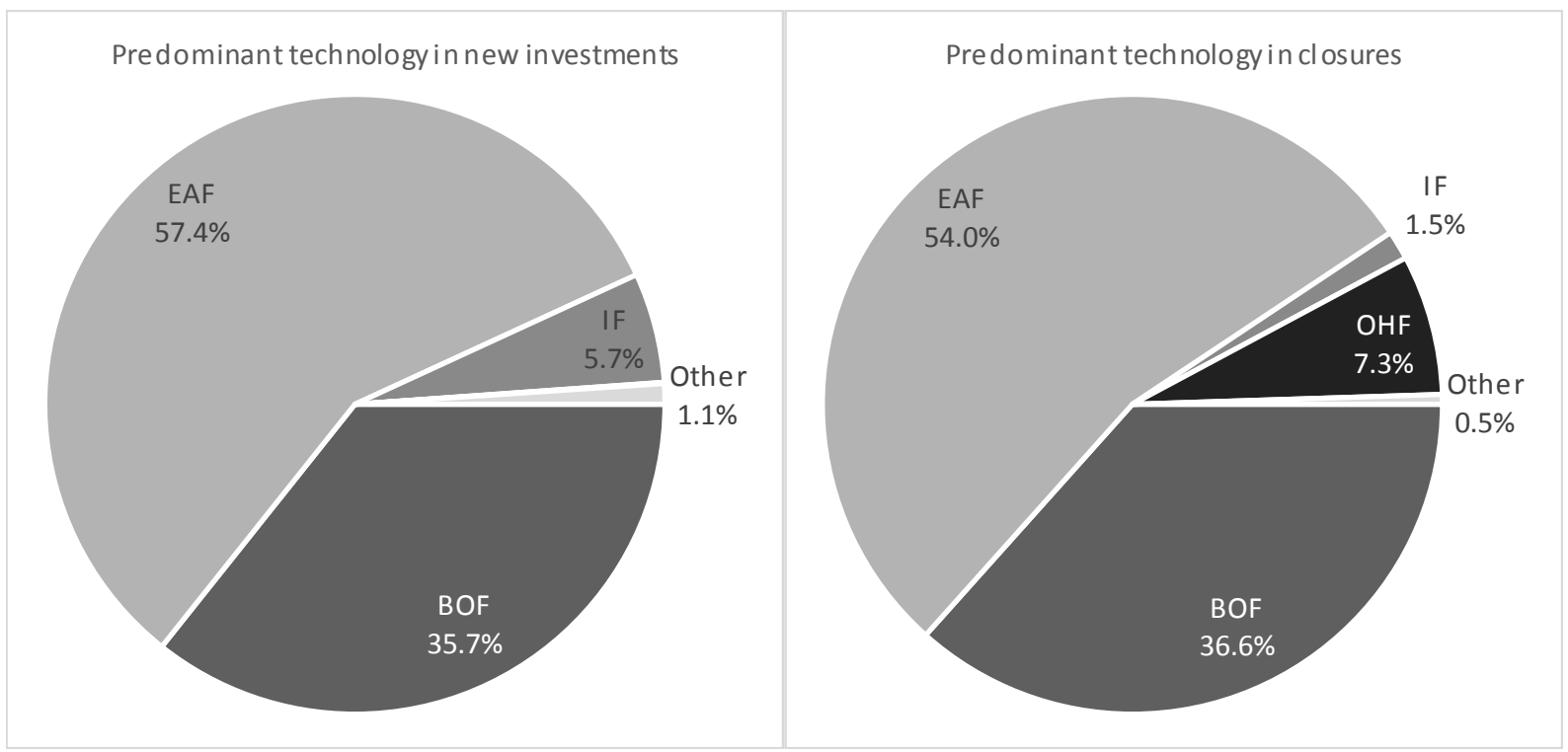

Note: The statistics for the predominant technology are calculated based on the number of new steelmaking equipment of the corresponding technology, namely: basic oxygen furnace (BOF), electric-arc furnace (EAF), open-hearth furnace (OHF), induction furnace (IF) and other or unidentified production technologies (Other). Source: OECD Steel database.

\subsection{Business structure and ownership}

Business structure and different ownership types can influence the ability of firms to implement reforms and drive better performance. Data from the OECD Steel database already allows distinguishing some features of business structure and further improvements are foreseen - e.g. the inclusion of M\&A data in the short term and the development of a satellite database with information of ownership changes through time.

Currently available data shows that plants belonging to international groups have slightly higher profits per unit of capacity when compared to domestic producers (Figure 24.A). Having production units in different locations allows groups to manage fluctuations in local demand and cost structures. Similarly, multi-plant firms (and multi-equipment plants) tend to be more profitable than single-plant firms (Figure 25.A) ${ }^{14}$, which may be explained by the same principle of being able to better adjust to changing market conditions by shifting resources across plants (and within plants).

Both international groups and multi-plant firms have lower levels of indebtedness, when compared to domestic and single-plant producers (Figure 24.B; Figure 25.B), likely a result of better financial performance and leaner balance sheets. 
Figure 24. Comparing the financial performance of international groups with producers, 2000-2019

A. Profitability (profit margin)

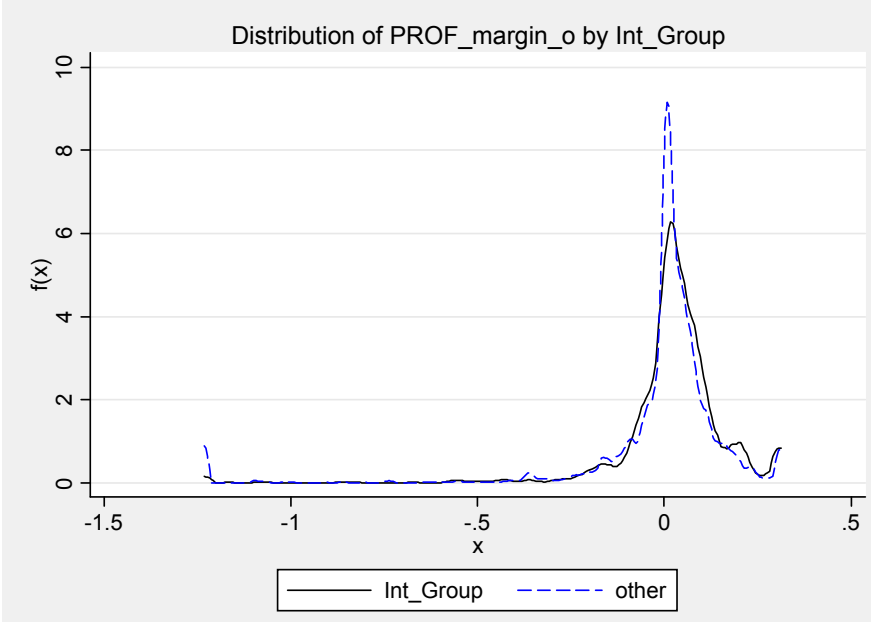

B. Indebtedness

Distribution of INDEBTEDNESS_o by Int_Group

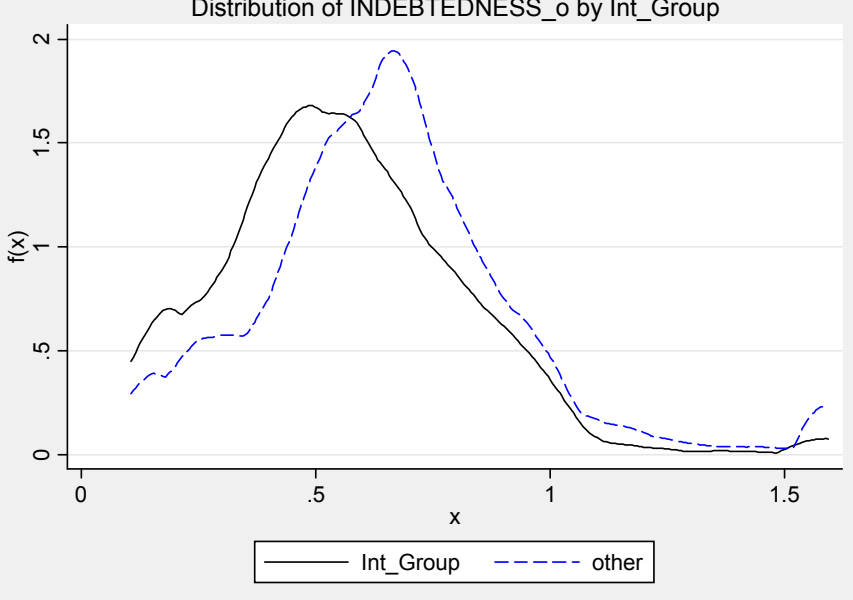

Note These figures plot the distributions of profitability (Panel A) and indebtedness (Panel B) for international groups (solid black line) and domestic plants (dashed blue line) using kernel density estimates. The kernel density estimate gives an approximation of the probability density function of a given distribution - up to a given point $\mathrm{x}$ in the horizontal axis, the area under this function provides the percentage of observations that have values that are lower or equal to $\mathrm{x}$. The total area below the curve for each year equals one. Please refer to Annex A for the definitions of the variables used. "Other" refers to domestic production units.

Source; OECD Steel database.

Figure 25. Comparing the financial performance of single- and multi-plant firms, 2000-2019

A. Profitability (profit margin)

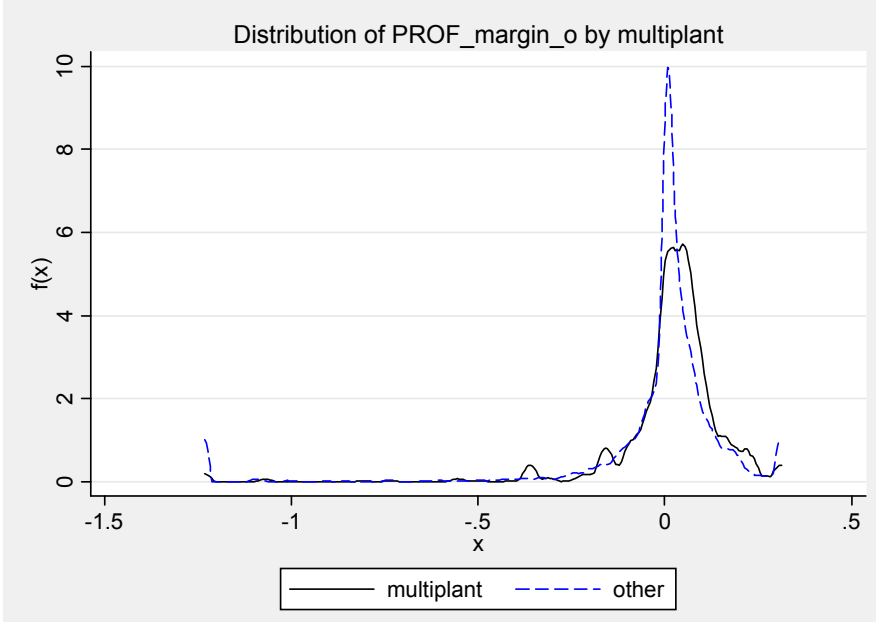

B. Indebtedness

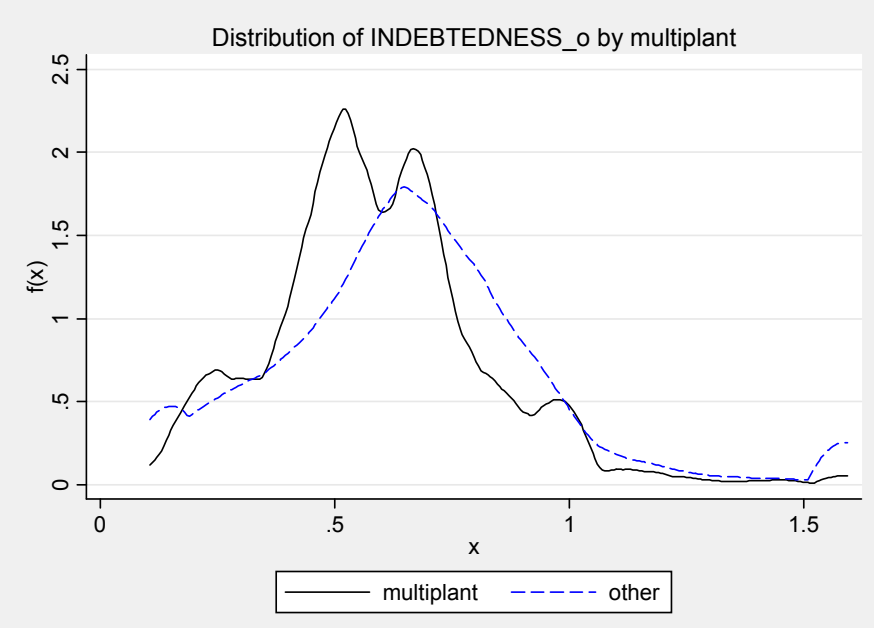

Note: These figures plot the distributions of profitability (Panel A) and indebtedness (Panel B) for multi-plant (solid black line) and single-plant firms (dashed blue line) using kernel density estimates. The kernel density estimate gives an approximation of the probability density function of a given distribution - up to a given point $\mathrm{x}$ in the horizontal axis, the area under this function provides the percentage of observations that have values that are lower or equal to $\mathrm{x}$. The total area below the curve for each year equals one. Please refer to Annex A for the definitions of the variables used. "Other" refers to single-plant firms.

Source: OECD Steel database. 
While information on different types of ownership status in the OECD Steel database is still being developed, ${ }^{15}$ data collected in the context of the Steel Committee's work on state enterprises (OECD, 2020 [24]), allows distinguishing the performance of companies that in 2019 were directly or indirectly owned (more than 50\%) by the state (state enterprises, SE) from other companies (private enterprises, PE) ${ }^{16}$ Results on the performance of SE are in line with the findings of Mattera and Silva $\left(2018_{[17]}\right)$ : SEs are less profitable and more indebted. In addition, SEs tend to have more liquidity problems, when compared to their private counterparts (Figure 26.A). Data on labour intensity also suggest that PEs are leaner (Figure 26.B). Further analysis based on changes in ownership over time would be warranted to clarify whether privatisation may help firms cope better with changing market conditions, as the preliminary evidence outlined in this paper suggests.

Figure 26. Comparing the performance of State enterprises with private companies, 2000-2019
A. Liquidity
B. Labour intensity
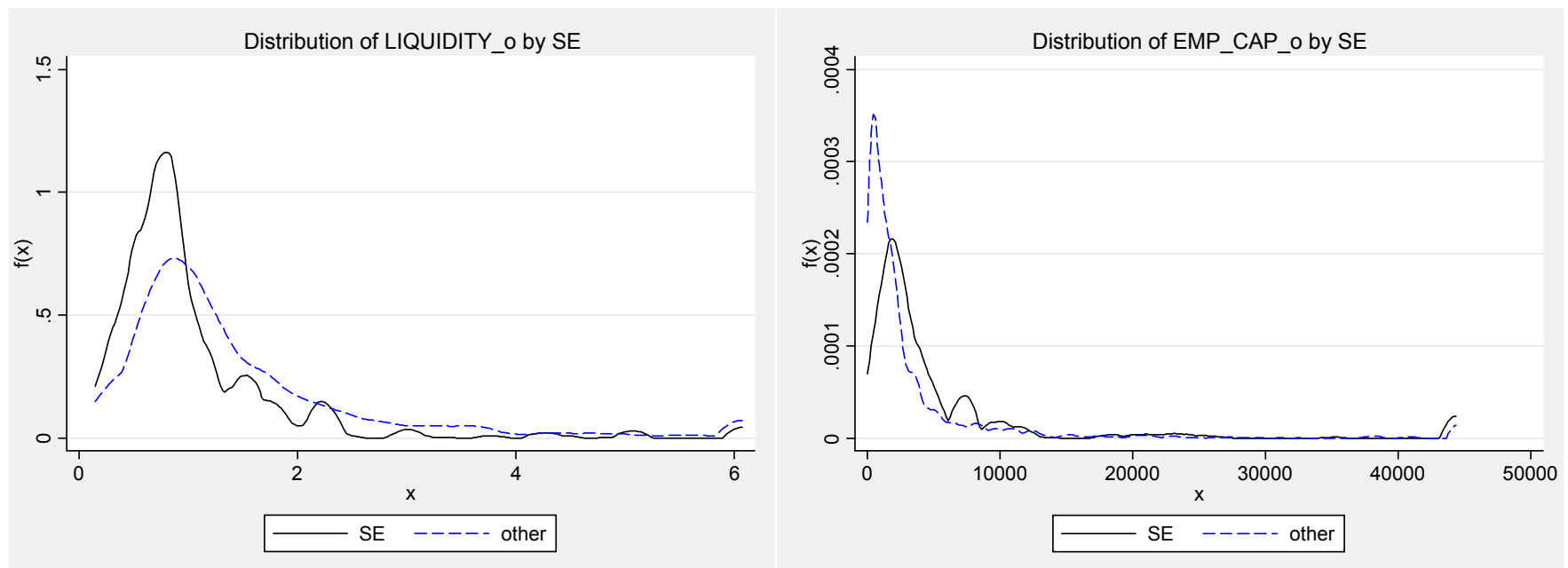

Note: While performance indicators vary over time, the ownership status (SE; PE) is constant and reflects ownership in 2019. "other" corresponds to PE.

Source: OECD Steel database and data work underlying OECD (2020[24]). 


\section{Concluding remarks and suggestions for further research}

\subsection{Summary}

The steel sector faced several challenges during the last two decades. This paper explores the wealth of information available from the newly assembled OECD Steel database to describe important characteristics of steelmaking plants and firms, as well as how these characteristics have evolved since 2000.

Data show that the 2008-09 financial crisis was an important turning point in the steel sector and sparked a long and pronounced excess capacity crisis. Structural change is needed to address persistent imbalances resulting in excess capacity, as well as to continue navigating through changing market conditions such as those brought about by the Covid19 pandemic or the implications of environmental challenges.

Results from the analyses in this paper indicate that the steel sector is characterised by low business dynamism and suggest that the market exit mechanism is not working efficiently, given the absence of any apparent relationship between plant closure and financial performance. Structural adjustment can take different forms and some degree of adjustment has nevertheless been taking place through changes in labour intensity, changing business structure and upgrading of outdated technology.

Technology may facilitate or hamper adjustment. Data suggest that neither EAF nor other more flexible technologies appear to yield better financial performance. Despite the sheer number of new investments in EAF technology, BOF technology continues to be the predominant steelmaking technology. Economies of scale seem to be the cornerstone in the sector.

Scale is also reflected business organisation. Data suggest that multi-plant firms perform better than single-plant firms and that international business groups may benefit from financial and other advantages. Capacity reductions or closures seem less likely to take place in multi-plant firms and in multinationals. Preliminary analysis using data on ownership suggests that state enterprises underperform - data on ownership changes are needed to investigate whether privatisation may help firms cope better with changing market conditions.

Equipment updates and replacement are important for steel companies to remain competitive. Even if these have been prevalent since the late 2000s, the vintage of currently installed capacity is relatively old. Large incumbents account for the majority of new investments in steelmaking capacity, which might reflect high set up costs and other barriers to entry.

The analyses in this paper highlight a number of characteristics that can help design policies that promote structural adjustment in the steel sector and resolve excess capacity. Market entry and exit mechanisms should be allowed to work, and restructuring through M\&A and changes in the internal organisation of companies' production units should be facilitated, insofar as it maintains competitive conditions and leads to a leaner industry, ready to tackle the challenges ahead. It would also be worth discussing incentives to upgrade technology towards more flexible, more efficient and cleaner production processes. 


\subsection{Future research}

The results of the analyses described in this paper are a first step into better understanding the micro determinants of changes in the steel sector. There are several avenues for further research and those described below are only selected suggestions. While some could be carried out by the OECD in the context of future work programmes of the Steel Committee, others are better suited for academic researchers, interested in contributing with evidence on the functioning of the steel sector.

\subsubsection{Developing indicators to monitor the evolution of the steel sector}

The Steel Committee will continue to monitor developments in steelmaking capacity and in steel markets. The newly assembled database could contribute with indicators that could be included in the regular market and capacity reports. These could include indicators of financial performance per unit of capacity and by technology, additional information on the structure (e.g. ownership), organisation (e.g. groups) and the performance of companies investing in new capacity, amongst others. As most of the data infrastructure is in place, the underlying work for this research mainly consist in the maintenance and update of the OECD steel database.

\subsubsection{Possible extensions to the OECD Steel database and topical analyses}

\section{Changes in ownership through time}

The Steel Committee is conducting work on mergers and acquisitions, as well as on state enterprises in the steel sector. This work could be better integrated and combined with the OECD Steel database to offer further insights into how changes in ownership and in the organisation of steel companies can affect the performance and long term viability of the steel industry. The data infrastructure work would require combining the underlying data and retrieving historical information on changes in ownership.

\section{Innovation in the steel sector}

Innovation is an important driver of structural change and productivity growth (OECD, $\left.2015_{[25]}\right)$. For example, the introduction of the "minimill" in the 1960s brought important structural changes and productivity growth to the steel sector in the United States (CollardWexler and De Loecker, $\left.2015_{[9]}\right)$. As such, emerging steelmaking technologies such as hydrogen-based steelmaking could bring about considerable changes to the sector. It would therefore be important to keep track of innovation taking place in the steel sector and in particular which firms are investing in, developing and adopting new technologies. For example, data on steel producers from the OECD Steel database could be complemented with indicators on innovation and technological development based on information on patents from the OECD/STI Micro-data Lab. ${ }^{17}$ This would be particularly useful to track progress in steel technologies, even if linking the underlying data infrastructure could be resource intensive.

\section{Employment}

Structural adjustment often implies the transition of workers to more productive plants, firms or industries. Efficiency gains and other aggregate benefits of restructuring are normally more diffused and therefore less visible than the costs imposed on workers, making the relevant reforms potentially difficult to implement (Andrews and Saia, $\left.2017_{[26]}\right)$. Adjustment also requires having a skilled workforce that allows the industry to 
respond to changes in the market and in technology. A shortage of skilled employees would hamper the industry's growth and productivity.

Governments and policy makers can support industrial change by boosting incentives for manufacturing industries to invest in skills and by supporting the transition of workers, when needed. The development of the OECD Steel database revealed important data gaps regarding workers and their characteristics. Collecting detailed information in this area could help better understand the socio economic implications of restructuring in the steel sector to inform the design of labour market and education policies that facilitate adjustment in the steel sector while ensuring that a skills gap does not develop.

The OECD is conducting work on productivity and the use of skills in firms, using insights from new analysis combining information from firms and workers (LinkEED). Potential synergies between the LinkEED project and the OECD steel capacity database could be explored with a view to shed light on employment issues in the steel sector.

\section{Subsidies and other forms of government support}

The Steel Committee is working on subsidies and other forms of government support affecting the steel sector and developing the OECD Steel Subsidy database. The work includes collecting subsidies at the recipient level, which could be combined with the OECD Steel database to shed light on the characteristics of firms receiving support and the effects that such support may have on the performance and the dynamics of steel companies. The underlying data infrastructure work would entail merging the information from the OECD Steel subsidy database with the OECD Steel database. Any future work in this area will need to be steered by the Steel Committee. 


\section{Endnotes}

${ }^{1}$ Iran is rich in natural gas, a source of energy for direct reduced iron (DRI) production as part of the EAF route. China is rich in metallurgical coal and in iron ore, even if grades of iron ore with higher ferrous content are often imported from Australia and Brazil.

2 Please note that a firm in ORBIS refers to a legal entity in national registers. Plants and establishments do not necessarily/always have such legal status. The calculations for the coverage of ORBIS were made on the basis of the aggregation of the steelmaking capacity for all matched financial accounts in ORBIS - i.e. consolidated corporate accounts and unconsolidated accounts of business segments (plants) - for which some financial information is available (i.e. not missing/void).

${ }^{3}$ If the detailed information on each separate pieces of equipment is unknown, the database groups the different pieces of equipment of the same technology (e.g. three EAF).

${ }^{4}$ For the official international statistical units "Establishment" and "Enterprise", please refer to the UN definition, available at: https://unstats.un.org/unsd/isdts/docs/StatisticalUnits.pdf

${ }^{5}$ This statistic is necessarily lower for companies as many investments and closures are at the equipment level, without necessarily implying the creation or dissolution of a company.

${ }^{6}$ The higher growth rates for BOF are driven by investments in economies such as China and India, where local ferrous scrap availability is low.

${ }^{7}$ This is in line with Shin and Stulz (1998[31] $)$ who cast doubts on the efficiency of internal capital markets.

${ }^{8}$ For the purpose of the financial analyses, the term plant refers to all steelmaking plants that produce financial accounts. If the accounts are only available at the level of the corresponding parent company, the capacity of the plant is used to input the company's financial performance to the plant. The analyses of financial performance in this paper uses importance weights to correct for coverage biases in ORBIS. These weights assume that the OECD Steel database reflects the population of crude steelmaking companies in each economy and are calculated based on the capacity of individual observations and the relevant aggregate (economy or world total).

${ }^{9}$ With regards to other technologies, IFs tend to be slightly more profitable and have more cash, but are also more indebted. Plants with predominantly OHF technology are less profitable than plants using other technologies and are also more indebted, which is likely associated with the obsolescence of this technology.

${ }^{10}$ The chosen time periods alternate between growth and contraction/stagnation in the global steel market: i) 2000-2003; ii) 2004-2008; iii) 2009-2013, and iv) 2014-2018. Data suggest that plants with predominantly BOF technology might be overall more profitable, but associated with lower liquidity and higher debt levels across all periods. A more detailed analysis would be required to convincingly show whether flexibility results in any significant differences in performance.

${ }^{11}$ Regional factors (e.g. different cost structures, government support) are likely to explain much of the heterogeneity in financial performance observed across geographies - future work in this area could help disentangle the different factors explaining profitability in the steel sector

12 The share of EAF in total global steelmaking capacity is nevertheless eclipsed by the share of BOF capacity.

${ }^{13}$ Please note that given the lack of available information on small IF equipment in some developing economies, the statistics presented in this paper may underestimate the number of IF investments as well as total IF capacity. IF technology is also very heterogeneous and while certain IF equipment may be expensive to install and produce highly specialised steel products, other may be considerably cheaper to install and operate, and be used to produce low grade steel products. See Hijikata (2020[8]) for further details.

${ }^{14}$ Results for multi-equipment plants are similar to those of multi-plant firms and can be obtained upon request.

${ }^{15}$ Next steps for the OECD Steel database in the area of ownership include collecting information on whether a company is publicly listed (short-term) and on changes in ownership over time (long-term) 


\section{2}

${ }^{16}$ Please note that the definition of state enterprise used in this paper may differ from definitions used in other OECD work on state-owned enterprises. This definition was only used for the analyses described in this paper.

17 The STI Micro-data Lab is a data infrastructure project that collects and links large-scale administrative and commercial databases. Data include administrative data such as intellectual property (IP) assets and scientific publications, as well as information on companies from private providers. The Micro-data Lab serves as a platform for the development of new metrics and methodologies and feeds into a large range of policy-relevant analyses. See http://www.oecd.org/sti/inno/intellectual-property-statistics-andanalysis.htm. 


\section{References}

Andrews, D. and A. Saia (2017), "Coping with creative destruction: Reducing the costs of firm exit”, OECD Economics Department Working Papers, No. 1353, OECD Publishing, Paris, https://dx.doi.org/10.1787/bbb44644-en.

Bajgar, M. et al. (2020), "Coverage and representativeness of Orbis data”, OECD Science, Technology and Industry Working Papers, No. 2020/o6, OECD Publishing, Paris, https://dx.doi.org/10.1787/c7bdaa03-en.

Berthelot, Y. and P. Rayment (2007), Looking back and peering forward: A short history of the United Nations Economic Commission for Europe, 1947-2007, United Nations Economic Commission for Europe, Geneva, http://www.unece.org/fileadmin/DAM/publications/oes/LookingBackPeeringForward 1947 -2007.pdf. (accessed on 14 July 2020).

Collard-Wexler, A. and J. De Loecker (2015), "Reallocation and Technology: Evidence from the US Steel Industry”, American Economic Review, Vol. 105/1, pp. 131-171, http://dx.doi.org/10.1257/aer.2013009o.

Daniel, L. (2013), An assessment of the supply-demand balance for the main steelmaking raw materials, Unclassified OECD document DSTI/SU/SC(2013)7, Paris.

D'Costa, A. (1999), The global restructuring of the steel industry : innovatons, institutions, and industrial change, Routledge.

D'Costa, A. (1999), The global restructuring of the steel industry : innovatons, institutions, and industrial change, Routledge.

Dewenter, K., W. Novaes and R. Pettway (2001), "Visibility versus complexity in business groups: Evidence from Japanese Keiretsu”, Journal of Business, Vol. 74/1, pp. 79-100, http://dx.doi.org/10.1086/209664.

GFSEC (2017), Global Forum on Steel Excess Capacity Berlin Ministerial Report, GFSEC, Berlin, https://www.bmwi.de/Redaktion/EN/Downloads/global-forum-on-steel-excesscapacity-report.pdf? blob=publicationFile (accessed on 10 August 2020).

Hijikata, T. (2020), Latest developments in steelmaking capacity 2020, OECD Publishing, Paris, https://www.oecd.org/industry/ind/latest-developments-in-steelmaking-capacity-2020.pdf (accessed on 15 July 2020).

Mattera, G. and F. Silva (2018), "State enterprises in the steel sector", OECD Science, Technology and Industry Policy Papers, No. 53, OECD Publishing, Paris, https://dx.doi.org/10.1787/2a8adgcd-en. 
OECD (2020), "Business demography indicators ISIC Rev. 4”, Structural and Demographic Business Statistics (database), https://dx.doi.org/10.1787/9e2bbo5a-en (accessed on 7 October 2020).

OECD (2020), Cross-border investment by state enterprises, OECD internal working document DSTI/SC(2020)7, https://one.oecd.org/document/DSTI/SC(2020)7/en/pdf (accessed on 16 July 2020).

OECD (2020), Mergers and acquisitions, consolidation and plant dynamics: evidence from the steel sector, OECD internal working document DSTI/SC(2020)6/REV1, Paris, https://one.oecd.org/document/DSTI/SC(2020)6/en/pdf (accessed on 15 July 2020).

OECD (2020), Recent trade policy measures, OECD internal working document DSTI/SC(2020)4, Paris, https://one.oecd.org/document/DSTI/SC(2020)4/en/pdf (accessed on 16 July 2020).

OECD (2020), The OECD steel database, OECD internal document DSTI/SC(2020)5, Paris.

OECD (2017), A first look at the steel industry in the context of global value chains, http://dx.doi.org/DSTI/SC(2017)4 (accessed on 19 June 2019).

OECD (2017), Business Dynamics and Productivity, OECD Publishing, Paris, https://dx.doi.org/10.1787/9789264269231-en.

OECD (2017), Entrepreneurship at a Glance 2017, OECD Publishing, Paris, https://dx.doi.org/10.1787/entrepreneur_aag-2017-en.

OECD (2017), Steel market developments: Q4 2017, OECD, https://www.oecd.org/sti/ind/steelmarket-developments-Q42017.pdf (accessed on 28 March 2018).

OECD (2015), "Excess Capacity in the Global Steel Industry and the Implications of New Investment Projects", OECD Science, Technology and Industry Policy Papers, No. 18, OECD Publishing, Paris, https://dx.doi.org/10.1787/5js65x46nxhj-en.

OECD (2015), Greening Steel: Innovation for Climate Change Mitigation in the Steel Sector, OECD Publishing, Paris, https://www.oecd.org/sti/ind/Environmental-patents-steel.pdf (accessed on 24 July 2020).

OECD (2015), The Innovation Imperative: Contributing to Productivity, Growth and WellBeing, OECD Publishing, Paris, https://dx.doi.org/10.1787/9789264239814-en.

OECD (2014), Developments in Steelmaking Capacity of Non-OECD Economies 2013, OECD Publishing, Paris, https://dx.doi.org/10.1787/steel_non-oecd-2013-en-fr.

Rimini, M. et al. (2020), Barriers to exit in the steel sector, OECD unclassified document DSTI/SC(2019)16/FINAL, Paris, https://www.oecd.org/industry/ind/steel-data-andresources.htm.

Shin, H. and R. Stulz (1998), “Are Internal capital Markets Efficient?”, The Quarterly Journal of Economics, Vol. 113/2, pp. 531-552, http://dx.doi.org/10.1162/00335553985555676. 
Silva, F. and A. De Carvalho (2016), Research and development, innovation and productivity growth in the steel sector, Unclassified OECD document DSTI/SU/SC(2015)5/FINAL, http://www.oecd.org/officialdocuments/publicdisplaydocumentpdf/?cote=DSTI/SU/SC(201 5)5/FINAL\&docLanguage $=$ En (accessed on 14 July 2020).

Silva, F. and A. de Carvalho (2016), Evaluating the financial health of the steel industry, OECD Publishing, Paris, https://www.oecd.org/sti/ind/Evaluating-Financial-Health-SteelIndustry.pdf (accessed on 14 July 2020).

World Steel Association (2020), Global crude steel output increases by 3.4\% in 2019, https://www.worldsteel.org/media-centre/press-releases/2020/Global-crude-steel-outputincreases-by-3.4--in-2019.html (accessed on 29 January 2020).

World Steel Association (2019), STEEL STATISTICAL YEARBOOK 2019 Concise version, https://www.worldsteel.org/en/dam/jcr:7aa2a95d-448d-4c56-b62bb24.57fo67cd9/SSY19\%2520concise\%2520version.pdf (accessed on 28 January 2020).

worldsteel (2020), Raw Materials, https://www.worldsteel.org/steel-by-topic/rawmaterials.html (accessed on 10 August 2020). 


\section{Annex A. Variables and indicators used in the analyses}

\begin{tabular}{|c|c|c|}
\hline Variable & Definition & \\
\hline multiequip_N & Number of equipment owned by a plant & \\
\hline multiequip & Binary indicator of whether a plant has more than 1 equipment & \\
\hline multiplant_N & Number of plants owned by a company & \\
\hline multiplant & Binary indicator of whether a company has more than 1 plant & \\
\hline GROSS_add & $\begin{array}{l}\text { Gross capacity additions at equipment level }(\mathrm{mmt}) \\
\text { _wld } \\
\text { _economy } \\
\text { company_id }\end{array}$ & $\begin{array}{l}\text {...at world level } \\
\text {...at economy } \\
\text {...at company }\end{array}$ \\
\hline GROSS_close & $\begin{array}{l}\text { Gross capacity closures at equipment level (mmt) } \\
\text { _wld } \\
\text { _economy } \\
\text { _company_id }\end{array}$ & $\begin{array}{l}\text {...at world level } \\
\text {...at economy } \\
\text {...at company }\end{array}$ \\
\hline NET_chg & $\begin{array}{l}\text { Net capacity changes }(\mathrm{mmt}) \text {, of which: } \\
\text { _wld } \\
\text { _economy } \\
\text { company_id }\end{array}$ & $\begin{array}{l}\text {...at world level } \\
\text {...at economy } \\
\text {...at company }\end{array}$ \\
\hline TECH & $\begin{array}{l}\text { Categorical variable for Technology. The different technology are: } \\
\text { BOF } \\
\text { EAF } \\
\text { IF } \\
\text { OHF } \\
\text { Stlmk (other/unknown) }\end{array}$ & $\begin{array}{l}1 \\
2 \\
3 \\
4 \\
5\end{array}$ \\
\hline Type & $\begin{array}{l}\text { Encoded variable for type. The different codes/labels are: } \\
\text { closure } \\
\text { old } \\
\text { operating } \\
\text { plan } \\
\text { underway } \\
\text { unknown }\end{array}$ & $\begin{array}{l}1 \\
2 \\
3 \\
4 \\
5 \\
6\end{array}$ \\
\hline Size_cat & $\begin{array}{l}\text { Size brackets }[\mathrm{mmt}] \\
] 0 ; 0.5[ \\
{[0.5 ; 2[} \\
{[2 ; \mathrm{max}]}\end{array}$ & $\begin{array}{l}\text { Small } \\
\text { Medium } \\
\text { Large }\end{array}$ \\
\hline AGE & Age of the equipment & \\
\hline AGE_cat & $\begin{array}{l}\text { Age brackets } \\
] 0 ; 10[ \\
{[10 ; 20[} \\
{[20 ; 30[} \\
{[30 ; \text { max }]}\end{array}$ & $\begin{array}{l}1 \\
2 \\
3 \\
4\end{array}$ \\
\hline CAP & Capacity of the level of aggregation used for the financials (mmt) & \\
\hline PROF & Profit and loss before tax & \\
\hline PROF_margin & Profitability margin, calculated as PROF per unit of operating revenue turnover & \\
\hline INDEBTEDNESS & $\begin{array}{l}\text { Indebtedness= TOTAL Debt/Total Assets. The debt ratio measures a company's } \\
\text { leverage. A ratio greater than } 1 \text { shows that debt is larger than assets, thus it is } \\
\text { being funded by equity. }\end{array}$ & \\
\hline LIQUIDITY & $\begin{array}{l}\text { Current ratio. The current ratio is a liquidity ratio that measures a company's } \\
\text { ability to pay short-term obligations or those due within one year. A current ratio } \\
\text { below } 1 \text { means that the company does not have enough liquid assets to cover its } \\
\text { short-term liabilities. }\end{array}$ & \\
\hline
\end{tabular}




\begin{tabular}{|c|c|}
\hline SOLVENCY & $\begin{array}{l}\text { Solvency=Shareholders funds / Total assets (in \%). The solvency ratio helps } \\
\text { determine a company's ability to pay its long-term debt and other debt obligations. } \\
\text { A solvency ratio higher than } 20 \% \text { is considered to be financially sound }\end{array}$ \\
\hline EMP & Number of employees \\
\hline EMP_CAP & Employees per unit of steelmaking capacity \\
\hline Int_Group & Binary indicator whether plant belongs to an international group \\
\hline EXIT & $\begin{array}{l}\text { Binary indicator whether equipment was closed in that year } \\
\text { _[aggregate] Binary indicator whether there was a closure in [aggregate] that year } \\
\text { _[aggregate]_N } \mathrm{N}>>\text { Total number of exits in year by [aggregate] } \\
\text {, where aggregate is globally(wld), economy(economy), company(company_id) or } \\
\text { plant(plant_id) }\end{array}$ \\
\hline ENTRY & $\begin{array}{l}\text { Binary indicator whether equipment started operation in that year } \\
\text { _[aggregate] Binary indicator whether there was an entry in [aggregate] that year } \\
\text { _[aggregate]_N } \mathrm{N}>>\text { Total number of entries in year by [aggregate] } \\
\text {, where aggregate is globally(wld), economy(economy), company(company_id) or } \\
\text { plant(plant_id) }\end{array}$ \\
\hline Upgrade & $\begin{array}{l}\text { Binary indicator whether there was a major upgrade of equipment in a plant in } \\
\text { that year }\end{array}$ \\
\hline Firm_growth & Annual change in capacity at the company level [\%] \\
\hline SE & Binary indicator of whether a firm is a State Enterprise (constant, as of 2019) \\
\hline
\end{tabular}




\section{Annex B. Additional tables and figures}

\section{Table A B.1. Geographical coverage of the OECD Capacity and Steel databases as of 31 June 2020}

\begin{tabular}{|c|c|c|c|c|c|c|c|}
\hline \multicolumn{2}{|l|}{ Africa } & \multicolumn{2}{|l|}{ Asia } & \multicolumn{2}{|l|}{ Europe } & \multicolumn{2}{|l|}{ Latin America } \\
\hline Algeria & Complete & Bangladesh & Ongoing & Austria & Complete & Argentina & Complete \\
\hline Angola & Complete & Bhutan & Ongoing & Belgium & Complete & Brazil & Complete \\
\hline Botswana & Complete & Cambodia & Ongoing & Bulgaria & Complete & Bolivia & Ongoing \\
\hline Cameroon & Complete & China (People's Republic of) & Complete & Croatia & Complete & Chile & Complete \\
\hline Democratic Republic of Congo & Complete & Chinese Taipei & Complete & Cyprus & Complete & Colombia & Complete \\
\hline Cote d'Ivoire & Ongoing & India & Complete & Czech Republic & Complete & Costa Rica & Ongoing \\
\hline Ethiopia & Complete & Japan & Complete & Estonia & Complete & Dominican Republic & Ongoing \\
\hline Gabon & Complete & Korea & Complete & Finland & Complete & Ecuador & Complete \\
\hline Ghana & Complete & \multicolumn{2}{|c|}{ Democratic People's Republic of Korea Ongoing } & France & Complete & El Salvador & Ongoing \\
\hline Kenya & Complete & Lao People's Democratic Republic & Ongoing & Germany & Complete & Guatemala & Complete \\
\hline Libya & Complete & Malaysia & Complete & Greece & Complete & Panama & Ongoing \\
\hline Mauritius & Ongoing & Mongolia & Ongoing & Hungary & Complete & Paraguay & Complete \\
\hline Morocco & Complete & Myanmar & Ongoing & Ireland & Complete & Peru & Complete \\
\hline Namibia & Complete & Pakistan & Ongoing & Latvia & Complete & Trinidad Tobago & Ongoing \\
\hline Nigeria & Complete & Philippines & Complete & Lithuania & Complete & Uruguay & Complete \\
\hline South Africa & Complete & Singapore & Complete & Luxembourg & Complete & Venezuela & Complete \\
\hline Sudan & Complete & Sri Lanka & Complete & Malta & Complete & & \\
\hline Tanzania & Complete & Thailand & Capacity only & Netherlands & Complete & & \\
\hline Togo & Ongoing & Viet Nam & Complete & Poland & Complete & Middle East & \\
\hline Tunisia & Ongoing & & & Portugal & Complete & Afghanistan & Ongoing \\
\hline Uganda & Complete & & & Romania & Complete & Bahrain & Complete \\
\hline Zambia & Complete & CIS & & Slovak Republic & Complete & Iran & Capacity only \\
\hline Zimbabwe & Complete & Armenia & Complete & Slovenia & Complete & Iraq & Complete \\
\hline & & Azerbaijan & Complete & Spain & Complete & Israel & Complete \\
\hline & & Belarus & Complete & Sweden & Complete & Jordan & Complete \\
\hline NAFTA & & Georgia & Complete & Albania & Ongoing & Kuwait & Complete \\
\hline Mexico & Complete & Moldova & Complete & Montenegro & Ongoing & Qatar & Complete \\
\hline & & Russia & Complete & North Macedonia & Ongoing & Saudi Arabia & Complete \\
\hline & & Turkmenistan & Complete & Norway & Ongoing & Syria & Complete \\
\hline & & Ukraine & Complete & Serbia & Ongoing & United Arab Emirates & Complete \\
\hline Dceania & & Uzbekistan & Complete & Switzerland & Complete & Yemen & Complete \\
\hline Australia & Complete & & & Turkey & Complete & & \\
\hline New Zealand & Complete & & & United Kingdom & Complete & & \\
\hline
\end{tabular}

Note: The table identifies whether the coverage of steelmaking production units by jurisdiction (operating in any given period between 2000 and 2019) was complete by 31 June 2020 or is still part of ongoing work. The full list of economies is based on the OECD Steelmaking Capacity database: http://oe.cd/steelcapacity.

Note by Turkey: The information in this document with reference to "Cyprus" relates to the southern part of the Island. There is no single authority representing both Turkish and Greek Cypriot people on the Island. Turkey recognizes the Turkish Republic of Northern Cyprus (TRNC). Until a lasting and equitable solution is found within the context of United Nations, Turkey shall preserve its position concerning the "Cyprus" issue. Note by all the European Union Member States of the OECD and the European Union: The Republic of Cyprus is recognized by all members of the United Nations with the exception of Turkey. The information in this document relates to the area under the effective control of the Government of the Republic of Cyprus.

Source: OECD Steel database 
Figure A B.1. OECD Steel database and ORBIS coverage, 2000-2019

A. Number of companies

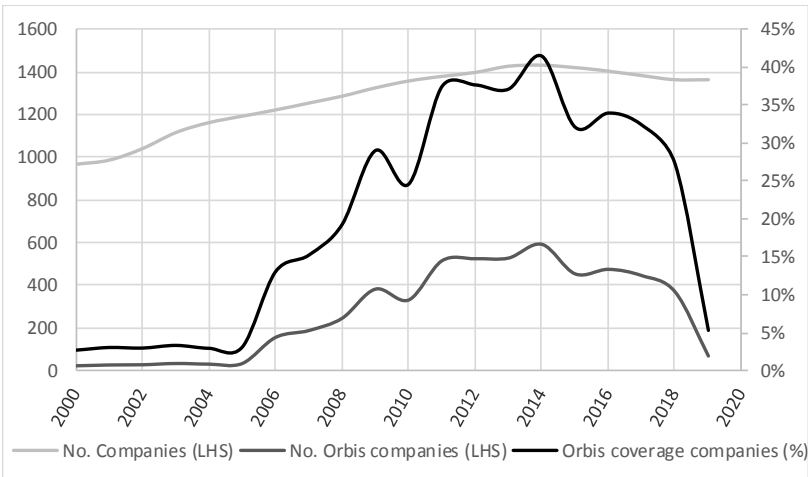

B. Number of companies and share of capacity

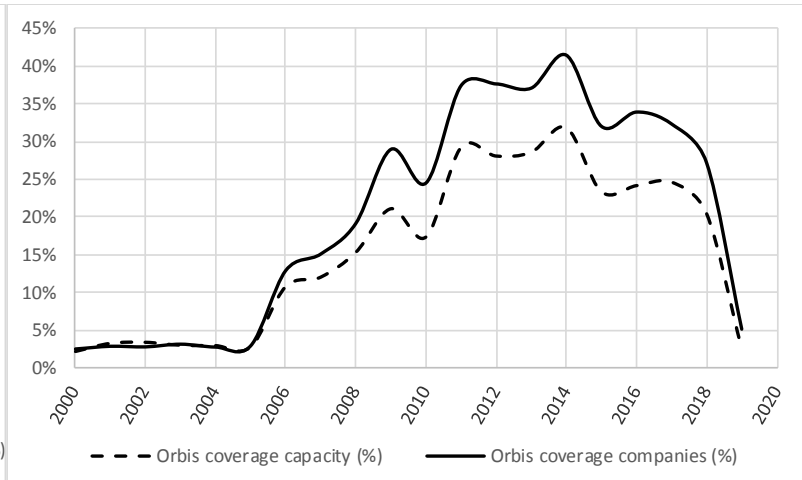

Note: The smaller coverage of ORBIS in 2019 results from the timing of the availability of the latest ORBIS database vintage, which was released on the same year (2019), and is thus lacking the financial accounts of a number of steel firms for the year 2019. The Secretariat expects that the upcoming vintage of ORBIS will contain more observations for the year2019, similar to at least the 2018 coverage.

Source: OECD calculations based on the OECD Steel database and ORBIS.

The analyses in this paper that requires data from ORBIS is carried out upon a subsample of firms. Therefore, the statistical analysis resorts to use of importance weights to correct for coverage biases in ORBIS. These weights assume that the OECD Steel database reflects the population of crude steelmaking equipment in each plant, company and economy and are calculated based on the capacity of individual observations and the relevant aggregate (economy or world total). For example, the calculation of weights for the economy aggregate is as follows:

$$
\text { weight_economy }_{k}=\text { capacity }_{i, t, k} / \sum_{i=1}^{N} \text { capacity }_{i, t, k}
$$

, where $i$ is the individual capacity observation for each equipment at year $t$ in economy $k$. $N$ is the total number of equipment that exist in economy $k$. 
Table A B.2. Coverage of the top 30 steel producing economies

Share of crude steelmaking capacity covered by non-empty observations in ORBIS (\%), 2000-2019

\begin{tabular}{|c|c|c|c|c|c|c|c|c|c|c|c|c|c|c|c|c|c|c|c|c|}
\hline Economy & 2000 & 2001 & 2002 & 2003 & 2004 & 2005 & 2006 & 2007 & 2008 & 2009 & 2010 & 2011 & 2012 & 2013 & 2014 & 2015 & 2016 & 2017 & 2018 & 2019 \\
\hline Algeria & $0.0 \%$ & $0.0 \%$ & $0.0 \%$ & $0.0 \%$ & $40.0 \%$ & $0.0 \%$ & $0.0 \%$ & $0.0 \%$ & $0.0 \%$ & $0.0 \%$ & $54.5 \%$ & $39.4 \%$ & $57.6 \%$ & $46.7 \%$ & $68.9 \%$ & $68.9 \%$ & $55.6 \%$ & $42.2 \%$ & $0.0 \%$ & $0.0 \%$ \\
\hline Austria & $0.0 \%$ & $0.0 \%$ & $0.0 \%$ & $0.0 \%$ & $0.0 \%$ & $0.0 \%$ & $2.3 \%$ & $0.0 \%$ & $0.0 \%$ & $3.8 \%$ & $3.5 \%$ & $3.5 \%$ & $3.5 \%$ & $3.5 \%$ & $3.5 \%$ & $3.5 \%$ & $3.5 \%$ & $3.5 \%$ & $0.0 \%$ & $0.0 \%$ \\
\hline Belgium & $0.0 \%$ & $0.0 \%$ & $0.0 \%$ & $0.0 \%$ & $0.0 \%$ & $0.0 \%$ & $0.0 \%$ & $0.0 \%$ & $0.0 \%$ & $56.2 \%$ & $57.7 \%$ & $44.9 \%$ & $54.8 \%$ & $60.6 \%$ & $58.0 \%$ & $58.0 \%$ & $5.6 \%$ & $5.6 \%$ & $56.2 \%$ & $0.0 \%$ \\
\hline Brazil & $0.0 \%$ & $2.6 \%$ & $0.0 \%$ & $2.5 \%$ & $2.5 \%$ & $2.5 \%$ & $2.4 \%$ & $0.0 \%$ & $0.0 \%$ & $2.6 \%$ & $0.0 \%$ & $0.0 \%$ & $0.0 \%$ & $0.0 \%$ & $11.9 \%$ & $11.8 \%$ & $16.5 \%$ & $14.4 \%$ & $7.7 \%$ & $0.0 \%$ \\
\hline Canada & $28.4 \%$ & $28.4 \%$ & $28.4 \%$ & $28.4 \%$ & $28.7 \%$ & $28.7 \%$ & $28.7 \%$ & $0.0 \%$ & $0.0 \%$ & $0.0 \%$ & $0.0 \%$ & $0.0 \%$ & $0.0 \%$ & $0.0 \%$ & $0.0 \%$ & $0.0 \%$ & $0.0 \%$ & $0.0 \%$ & $0.0 \%$ & $0.0 \%$ \\
\hline China & $2.3 \%$ & $1.0 \%$ & $0.7 \%$ & $0.2 \%$ & $0.5 \%$ & $0.8 \%$ & $20.2 \%$ & $21.4 \%$ & $26.0 \%$ & $23.6 \%$ & $11.1 \%$ & $37.0 \%$ & $34.4 \%$ & $34.2 \%$ & $42.0 \%$ & $24.5 \%$ & $26.3 \%$ & $25.2 \%$ & $21.7 \%$ & $0.0 \%$ \\
\hline Chinese Taipei & $0.0 \%$ & $0.0 \%$ & $0.0 \%$ & $0.0 \%$ & $0.0 \%$ & $0.0 \%$ & $0.0 \%$ & $8.8 \%$ & $5.5 \%$ & $10.8 \%$ & $9.8 \%$ & $13.5 \%$ & $8.7 \%$ & $11.7 \%$ & $12.0 \%$ & $11.4 \%$ & $8.3 \%$ & $8.0 \%$ & $11.7 \%$ & $0.0 \%$ \\
\hline Egypt & $0.0 \%$ & $0.0 \%$ & $0.0 \%$ & $0.0 \%$ & $1.6 \%$ & $1.4 \%$ & $1.4 \%$ & $1.4 \%$ & $0.0 \%$ & $21.1 \%$ & $21.1 \%$ & $21.1 \%$ & $10.6 \%$ & $8.3 \%$ & $8.4 \%$ & $8.4 \%$ & $6.9 \%$ & $6.5 \%$ & $6.5 \%$ & $0.0 \%$ \\
\hline France & $3.8 \%$ & $3.8 \%$ & $3.5 \%$ & $3.5 \%$ & $5.4 \%$ & $1.9 \%$ & $2.0 \%$ & $10.4 \%$ & $7.1 \%$ & $42.1 \%$ & $42.3 \%$ & $42.6 \%$ & $42.6 \%$ & $46.1 \%$ & $48.6 \%$ & $46.1 \%$ & $46.1 \%$ & $47.2 \%$ & $47.2 \%$ & $0.0 \%$ \\
\hline Germany & $0.0 \%$ & $0.0 \%$ & $0.0 \%$ & $0.0 \%$ & $0.0 \%$ & $0.0 \%$ & $0.7 \%$ & $5.4 \%$ & $19.3 \%$ & $30.4 \%$ & $30.0 \%$ & $30.0 \%$ & $30.2 \%$ & $29.6 \%$ & $30.2 \%$ & $30.1 \%$ & $25.5 \%$ & $30.1 \%$ & $10.3 \%$ & $0.0 \%$ \\
\hline India & $0.1 \%$ & $0.1 \%$ & $0.2 \%$ & $1.0 \%$ & $0.6 \%$ & $0.6 \%$ & $1.7 \%$ & $2.3 \%$ & $5.2 \%$ & $12.2 \%$ & $27.8 \%$ & $23.2 \%$ & $24.1 \%$ & $24.7 \%$ & $29.3 \%$ & $26.7 \%$ & $26.1 \%$ & $22.5 \%$ & $21.6 \%$ & $13.9 \%$ \\
\hline $\begin{array}{l}\text { Indonesia } \\
\text { Iran }\end{array}$ & $0.0 \%$ & $0.0 \%$ & $0.0 \%$ & $1.7 \%$ & $3.7 \%$ & $0.0 \%$ & $1.7 \%$ & $1.7 \%$ & $0.0 \%$ & $3.7 \%$ & $3.6 \%$ & $1.6 \%$ & $4.8 \%$ & $1.4 \%$ & $1.4 \%$ & $1.4 \%$ & $1.4 \%$ & $1.4 \%$ & $3.0 \%$ & $0.0 \%$ \\
\hline Italy & $9.4 \%$ & $4.9 \%$ & $37.9 \%$ & $33.8 \%$ & $34.2 \%$ & $33.8 \%$ & $33.8 \%$ & $33.4 \%$ & $34.4 \%$ & $55.0 \%$ & $57.8 \%$ & $58.8 \%$ & $28.7 \%$ & $27.5 \%$ & $27.7 \%$ & $29.5 \%$ & $33.9 \%$ & $36.1 \%$ & $35.8 \%$ & $0.0 \%$ \\
\hline Japan & $3.2 \%$ & $9.0 \%$ & $3.8 \%$ & $0.3 \%$ & $0.3 \%$ & $0.3 \%$ & $0.3 \%$ & $0.0 \%$ & $0.0 \%$ & $3.2 \%$ & $24.1 \%$ & $11.7 \%$ & $16.2 \%$ & $10.7 \%$ & $13.5 \%$ & $15.0 \%$ & $15.0 \%$ & $17.4 \%$ & $14.7 \%$ & $18.3 \%$ \\
\hline Korea & $0.0 \%$ & $0.0 \%$ & $0.0 \%$ & $0.0 \%$ & $0.0 \%$ & $0.0 \%$ & $0.0 \%$ & $0.0 \%$ & $0.6 \%$ & $14.8 \%$ & $11.8 \%$ & $18.4 \%$ & $15.6 \%$ & $32.8 \%$ & $5.8 \%$ & $10.9 \%$ & $10.6 \%$ & $28.9 \%$ & $13.5 \%$ & $0.0 \%$ \\
\hline Malaysia & $0.0 \%$ & $0.0 \%$ & $0.0 \%$ & $0.0 \%$ & $0.0 \%$ & $0.0 \%$ & $11.7 \%$ & $21.8 \%$ & $22.4 \%$ & $68.3 \%$ & $59.4 \%$ & $60.9 \%$ & $75.5 \%$ & $54.5 \%$ & $54.8 \%$ & $71.3 \%$ & $76.9 \%$ & $60.0 \%$ & $35.1 \%$ & $7.8 \%$ \\
\hline Mexico & $2.9 \%$ & $2.6 \%$ & $2.6 \%$ & $5.3 \%$ & $2.9 \%$ & $2.9 \%$ & $5.0 \%$ & $2.5 \%$ & $4.9 \%$ & $10.8 \%$ & $10.6 \%$ & $10.4 \%$ & $16.3 \%$ & $13.5 \%$ & $13.2 \%$ & $11.0 \%$ & $14.6 \%$ & $12.2 \%$ & $11.0 \%$ & $0.0 \%$ \\
\hline Netherlands & $0.0 \%$ & $0.0 \%$ & $0.0 \%$ & $0.0 \%$ & $0.0 \%$ & $0.0 \%$ & $0.0 \%$ & $0.0 \%$ & $0.0 \%$ & $0.0 \%$ & $96.6 \%$ & $100.0 \%$ & $100.0 \%$ & $100.0 \%$ & $96.6 \%$ & $96.6 \%$ & $96.6 \%$ & $96.6 \%$ & $96.6 \%$ & $96.6 \%$ \\
\hline Poland & $0.0 \%$ & $0.0 \%$ & $10.8 \%$ & $10.8 \%$ & $0.0 \%$ & $0.6 \%$ & $11.4 \%$ & $60.5 \%$ & $60.5 \%$ & $95.0 \%$ & $95.0 \%$ & $95.0 \%$ & $94.4 \%$ & $94.4 \%$ & $94.4 \%$ & $94.4 \%$ & $94.4 \%$ & $94.4 \%$ & $94.4 \%$ & $0.0 \%$ \\
\hline Russia & $0.0 \%$ & $5.4 \%$ & $3.0 \%$ & $6.2 \%$ & $6.2 \%$ & $6.4 \%$ & $1.2 \%$ & $4.2 \%$ & $12.4 \%$ & $30.8 \%$ & $39.4 \%$ & $25.0 \%$ & $29.9 \%$ & $35.4 \%$ & $26.8 \%$ & $34.4 \%$ & $32.1 \%$ & $37.5 \%$ & $30.5 \%$ & $0.0 \%$ \\
\hline Saudi Arabia & $0.0 \%$ & $0.0 \%$ & $0.0 \%$ & $0.0 \%$ & $0.0 \%$ & $0.0 \%$ & $0.0 \%$ & $0.0 \%$ & $0.0 \%$ & $0.0 \%$ & $0.0 \%$ & $0.0 \%$ & $0.0 \%$ & $0.0 \%$ & $0.0 \%$ & $0.0 \%$ & $0.0 \%$ & $0.0 \%$ & $0.0 \%$ & $0.0 \%$ \\
\hline South Africa & $0.0 \%$ & $0.0 \%$ & $0.0 \%$ & $0.0 \%$ & $8.3 \%$ & $8.3 \%$ & $8.3 \%$ & $8.3 \%$ & $8.3 \%$ & $8.3 \%$ & $8.3 \%$ & $8.3 \%$ & $15.2 \%$ & $14.9 \%$ & $0.0 \%$ & $0.0 \%$ & $0.0 \%$ & $0.0 \%$ & $0.0 \%$ & $0.0 \%$ \\
\hline $\begin{array}{l}\text { Spain } \\
\text { Thailand }\end{array}$ & $7.8 \%$ & $7.8 \%$ & $7.8 \%$ & $7.8 \%$ & $7.5 \%$ & $2.8 \%$ & $2.8 \%$ & $2.8 \%$ & $7.9 \%$ & $25.0 \%$ & $30.2 \%$ & $30.3 \%$ & $28.7 \%$ & $32.7 \%$ & $24.8 \%$ & $32.7 \%$ & $33.6 \%$ & $32.7 \%$ & $24.1 \%$ & $0.0 \%$ \\
\hline Turkey & $0.0 \%$ & $1.5 \%$ & $0.0 \%$ & $0.4 \%$ & $0.0 \%$ & $17.5 \%$ & $15.7 \%$ & $15.5 \%$ & $16.2 \%$ & $21.5 \%$ & $24.1 \%$ & $37.4 \%$ & $39.8 \%$ & $44.8 \%$ & $45.4 \%$ & $36.0 \%$ & $42.9 \%$ & $33.9 \%$ & $33.1 \%$ & $0.0 \%$ \\
\hline Ukraine & $0.0 \%$ & $0.0 \%$ & $0.0 \%$ & $0.0 \%$ & $0.0 \%$ & $0.0 \%$ & $0.0 \%$ & $0.0 \%$ & $0.0 \%$ & $33.1 \%$ & $18.9 \%$ & $21.9 \%$ & $15.1 \%$ & $32.9 \%$ & $25.5 \%$ & $28.7 \%$ & $28.7 \%$ & $33.2 \%$ & $20.2 \%$ & $0.0 \%$ \\
\hline United K & $0.9 \%$ & $0.9 \%$ & $0.9 \%$ & $0.0 \%$ & $0.0 \%$ & $0.0 \%$ & $0.0 \%$ & $0.0 \%$ & $0.0 \%$ & $7.2 \%$ & $28.6 \%$ & $28.6 \%$ & $50.5 \%$ & $47.9 \%$ & $31.3 \%$ & $37.9 \%$ & $52.1 \%$ & $81.4 \%$ & $85.5 \%$ & $37.2 \%$ \\
\hline United States & $0.8 \%$ & $0.8 \%$ & & $1.3 \%$ & $0.8 \%$ & $0.5 \%$ & $0.0 \%$ & $0.0 \%$ & $0.0 \%$ & $3.9 \%$ & $4.0 \%$ & $4.4 \%$ & $4.4 \%$ & $4.5 \%$ & $4.5 \%$ & $4.6 \%$ & $4.6 \%$ & $4.6 \%$ & $4.6 \%$ & $0.1 \%$ \\
\hline Viet Nam & $0.0 \%$ & $0.0 \%$ & $0.0 \%$ & $0.0 \%$ & $0.0 \%$ & $0.0 \%$ & $0.0 \%$ & $4.3 \%$ & $24.9 \%$ & $49.4 \%$ & $47.1 \%$ & $39.8 \%$ & $13.2 \%$ & $10.0 \%$ & $42.4 \%$ & $35.7 \%$ & $30.2 \%$ & $56.9 \%$ & $19.5 \%$ & $0.0 \%$ \\
\hline
\end{tabular}

Note: The table shows the share of the steelmaking capacity that is matched with non-empty ORBIS entries, by economy and year. ORBIS observations that have void information are excluded from these calculations. ORBIS data are not yet matched for Iran and Thailand.

Source: OECD calculations based on the OECD Steel database and ORBIS. 
Figure A B.2. Financial performance by technology
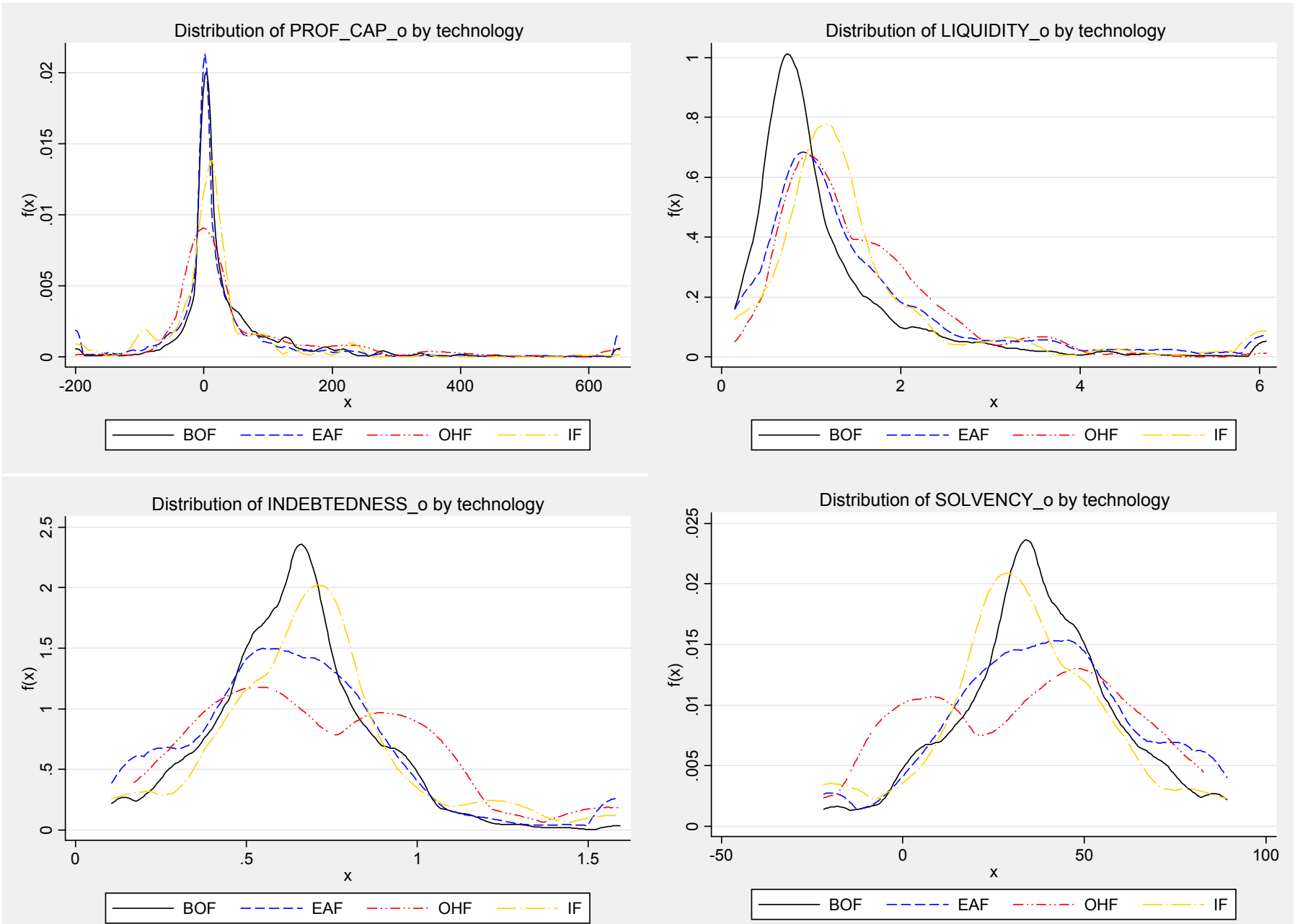

Source: OECD Steel database. 
Figure A B.3. Average annual firm growth across different dimensions, 2009-2019
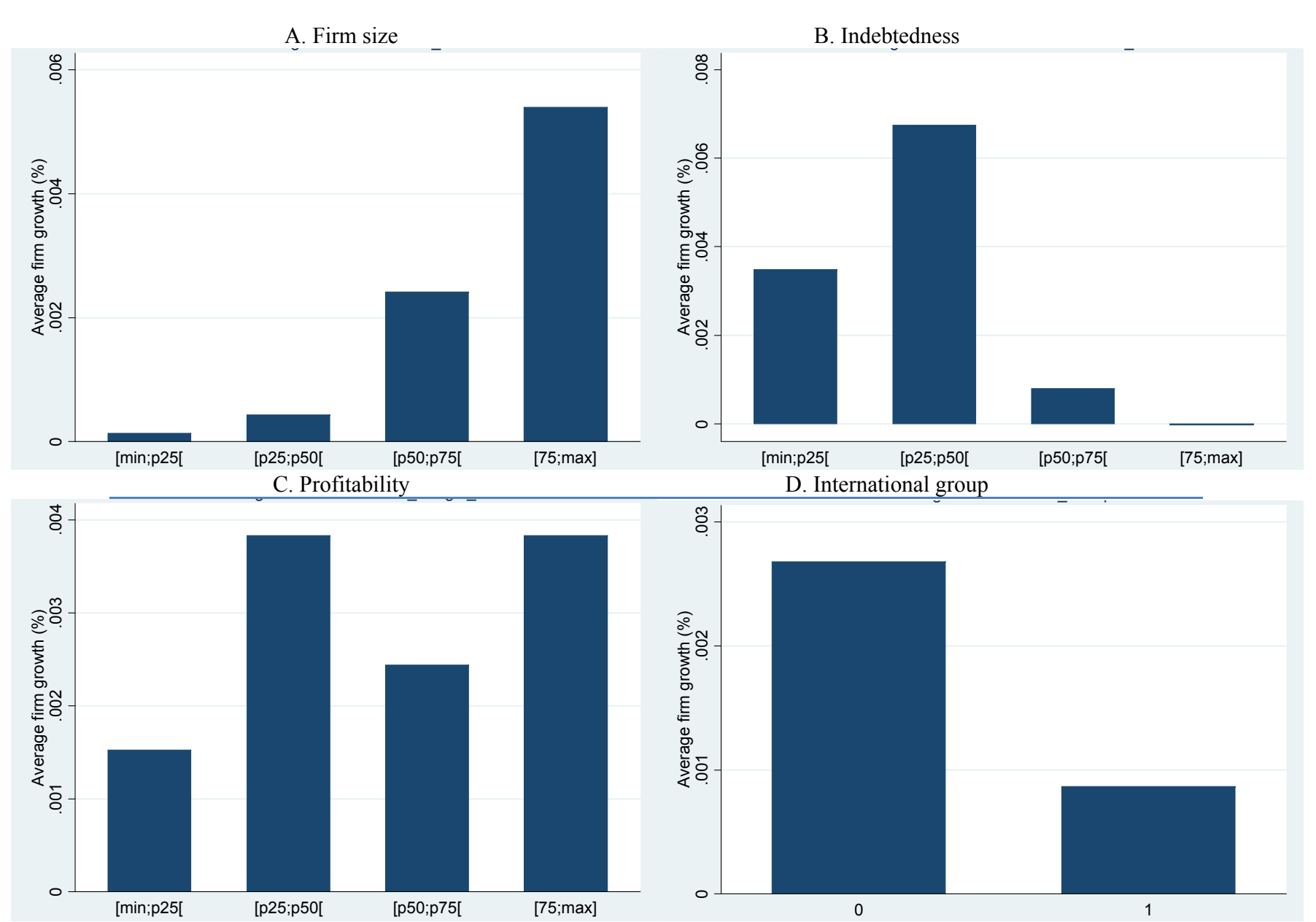

Note: This figure plots the average annual growth in steelmaking capacity (at the company level) for different categories across all years and all firms. The growth rates are small because the vast majority (84.2\%) of steel companies did not invest during the period 2000-2019.

Source: OECD Steel database. 